\title{
Paranın Dolaşım Hızının ve Para Talebi Fonksiyonunun Ekonometrik Analizi: Türkiye Örneği*
}

\author{
Ufuk Can1 $\odot$, Zeynep Gizem Can² ๑, Süleyman Değirmen ${ }^{\circledR}$
}

Öz

Bu çalışmanın amacı Türkiye için paranın dolaşım hızının durağanlığını test etmek ve paranın dolaşım hızını etkileyen değişkenleri belirlemektir. 1970-2017 yıllarını kapsayan dönem için veri seti yıllık frekansta oluşturulmakta; paranın dolaşım hızı, reel gelir, mevduat faiz oranı ve reel efektif döviz kuru değişkenler olarak kullanılmaktadır. Geleneksel ve doğrusal olmayan birim kök testleri, varyans oranı testleri ve kesirli bütünleşme testleri paranın dolaşım hızının durağan olmadığı gösterse de 2000'li yıllarda yaşanan ekonomik ve yapısal dönüşümler kırılma olarak alındığında birçok yapısal kırılma içeren birim kök testine göre paranın dolaşım hızının durağan olması dikkat çekmektedir. Ayrıca, doğrusal olmayan gecikmesi dağıtılmış otoregresif model (NARDL) ile mevduat faiz oranlarının kısa dönem asimetrisi ve reel efektif döviz kurunun uzun ve kısa dönem asimetrisi anlamlı bulunmakta, uzun dönemde mevduat faiz oranlarındaki ve reel efektif döviz kurlarındaki pozitif değişimlerin negatif değişimlere göre paranın dolaşım hızı üzerinde daha etkili olduğu sonucuna ulaşılmaktadır. Para talebinin gelir esnekliğinin pozitif, faiz oranı esnekliğinin negatif ve döviz kuru esnekliğinin pozitif olduğu belirlenmekte ve analiz sonuçları literatürde yapılan çalışmalarla örtüşmektedir.

\section{Anahtar Kelimeler}

Paranın dolaşım hızı, Birim Kök Testleri, NARDL Modeli

JEL Sınıflandırması: C51, E41

\section{Econometric Analysis of Velocity of Money and Money Demand Function: The Case of Turkey}

\begin{abstract}
This study aims to test the stationarity of the velocity of money for Turkey and to determine the variables affecting the velocity of money. The annual data set covering the period from 1970 to 2017 contains the velocity of money, real income, deposit interest rate and real effective exchange rate variables. Although traditional and nonlinear unit root tests, variance ratio tests and fractional integration tests show that the velocity of money is not stationary, it is noteworthy that many of the structural breakpoint unit root tests' results support its stationarity taking into account the economic and structural transformations experienced in the 2000s. In addition, with the nonlinear autoregressive distributed lag model
\end{abstract}

\footnotetext{
* Bu çalışmada belirtilen görüşler yazarına ait olup, T.C. Merkez Bankası'nın görüşlerini yansıtmamaktadır.

1 Sorumlu Yazar: Ufuk Can (Uzm. Yard.), T.C. Merkez Bankası, Yapısal Ekonomik Araştırmalar Genel Müdürlüğü, Adana, Türkiye. E-posta: ufuk.can@tcmb.gov.tr ORCID: 0000-0002-5398-5769

2 Zeynep Gizem Can (Doktora Öğrencisi), Çukurova Üniversitesi, İktisadi ve İdari Bilimler Fakültesi, iktisat Bölümü, Adana, Türkiye. E-posta: gizem5387@hotmail.com ORCID: 0000-0002-2852-4995

3 Süleyman Değirmen (Prof. Dr.), Mersin Üniversitesi, iktisadi ve İdari Bilimler Fakültesi, iktisat Bölümü, Adana, Türkiye.

E-posta: sdegirmen@mersin.edu.tr ORCID: 0000-0001-8750-652X

Atıf: Can, U., Can, Z. G. ve Degirmen, S. (2019). Paranın dolaşım hızının ve para talebi fonksiyonunun ekonometrik analizi: Türkiye örneği. Istanbul Business Research, 48(2), 218-247. http://doi.org/10.26650/ibr.2019.48.0054
} 
(NARDL), the short-term asymmetry of deposit interest rates and the long and short-term asymmetry of the real effective exchange rate are significant. The positive changes in deposit interest rates and real effective exchange rates over the long-term are more effective on the velocity of money than negative changes. The income, interest rate and exchange rate elasticity of money are respectively positive, negative and positive, and the results coincide with the studies in the literature.

\section{Keywords}

Velocity of Money, Unit Root Tests, NARDL Model

JEL Codes: C51, E41

\section{Extended Summary}

The stability and estimation of the money demand function and the velocity of money are crucial for the success of the monetary policy. Turkey, as a developing country, has been taking important steps towards financial and economic liberalization by changing the prevailing economic paradigm since 1980. The process of dollarization stemmed from important changes in financial deepening and diversification and also, the chronic high inflation caused economic agents to place more stable financial assets in their portfolios in order to protect the real purchasing power of their income and wealth. Therefore, this behavior affected the function of the money demand and reduced the effectiveness of the monetary policy. In this context, the aim of this study is to re-analyze the money demand function and velocity of money for Turkey with the data set covering 1970-2017 period.

This study uses a suitable methodology according to the scope of this study: the stationarity of the velocity of money is investigated by autocorrelation function, traditional, breakpoint and nonlinear unit root tests, variance ratio tests and fractional integration models (ARFIMA); and the money demand function based on McKinnon (1996) is also analyzed with the help of the non-linear autoregressive distributed lag (NARDL) model.

With regard to the velocity of money, the Ljung-Box autocorrelation test cannot reject the null hypothesis that the series has a unit root and is not stationary; the ADF, DF-GLS, PP and NP traditional unit root tests cannot reject the null hypothesis that the series has a unit root and is not stationary, while the KPSS test cannot accept the null hypothesis that the series is stationary. Breakpoint unit root tests such as CMR, PV, Perron, ZA, LP, LS1 and LS2 give contradictory results. When structural breaks are taken into account, the velocity of money may be stationary at the level. KSS and Sollis nonlinear unit root tests cannot reject the null hypothesis that the series has a unit root. Lo and McKinlay, Wright and Chow and Dening's variance ratio tests fail to reject the null hypothesis that the series follows a random walk process. Furthermore, Geweke and Porter-Hudak, Robinson and Phillips fractional integration tests seem unable to reject the null hypothesis that the series is not stationary. In brief, the velocity of money follows a random walk process and may be stable when structural breaks are taken into account, as opposed to traditional and nonlinear unit root tests, and fractional integration models. 
As the first order difference follows the stationary process, velocity of money, which is the dependent variable, and real gross domestic product, real effective exchange rate, savings deposits and interest rate, which are the explanatory variables, are analyzed with the NARDL bounds test to include the asymmetric effects of the cointegration relationship. It is stated that there is a long-term relationship between the variables in the estimated model. This model is stable within the framework of the Cusum and CusumQ test, and all diagnostic tests meet the assumptions of the model. In addition, the income, interest rate and exchange rate elasticity of money demand are positive, negative and positive, respectively. Income elasticity of money demand is positive, because money acts as a luxury commodity as income increases. The interest rate elasticity of money demand is negative for that interest rates reflect opportunity cost of money demand. The exchange rate elasticity of the money demand is positive due to the increase in wealth through the valuation of foreign assets held by economic agents as the national currency loses value.

Because the elasticity of interest rate and exchange rate of money demand is less and greater than one, the money demand is sensitive to the changes of these variable, respectively. For a stable money demand function, which is a prerequisite for the CBRT's inflation targeting regime, macroeconomic and financial stability policies need to be implemented so that they can control the interest rate and the real effective exchange rate. Furthermore, CBRT is considered as successful in the covered period in the study by virtue of the fact that the money demand function is stable even though the velocity of money is not stationary. 


\section{Paranın Dolaşım Hızının ve Para Talebi Fonksiyonunun Ekonometrik Analizi: Türkiye Örneği}

Uygulanan para politikasının başarısı, para talebi fonksiyonunun ve paranın dolaşım hızının istikrarlı olması ve tahmin edilebilmesi ile mümkün olmaktadır. Ball (2012) para politikası tasarlanırken paranın dolaşım hızındaki dalgalanmaların önem taşıdığını, Omer (2010) ve Tavlas (2015) paranın dolaşım hızının istikrarının ve öngörülebilirliğinin başarılı bir para politikası için gerekli olduğunu vurgulamaktadır.

Paranın dolaşım hızı ile ilgili çalışmalar para politikası ile ilgilenen uygulayıcıların ve akademisyenlerin en eski ve üzerinde en çok çalışma yaptığı konuların başında gelmektedir. Humphrey (1993) ve Karaman vd. (2019) paranın dolaşım hızı kavramının tarihçesinin 17. yüzyılda kadar dayandığını belirtmektedir. Pierre Boisguillebert gelir dağılımının, Richard Cantillion dış ticaret ve para talebi üzerinden belirlenen faiz hadlerinin, Henry Thornton enflasyon beklentilerinin paranın dolaşım hızıyla ilişkisini ortaya koymaktadır. William Petty paranın dolaşım hızı ile elde tutulan nakit miktarını ilişkilendirmekte, bu dolaşım hızını gelir, ödeme sıklığg1, ödeme hacmi, üretim düzeyi, faiz oranı, gelir dağılımı, finansal sistemin derinliği, bekleyişler gibi nitel ve nicel değişkenlere bağlamaktadır. Paranın dolaşım hızının diğer ekonomik olgularla ilişkilendirilmesi klasik miktar teorisinin ortaya çıkmasına zemin hazırlamakta, bu teoriyle birlikte paranın dolaşım hızının istikrarı sorgulanmaktadır.

Ekonomi literatüründe paranın dolaşım hızı ile ilgili yapılan ve öncü olarak kabul edilen teorik çerçeveli çalışmalarda paranın dolaşım hızının istikrarlı olup olmadığı üzerinde durulmaktadır. Fisher (1911) kısa dönemde para talebindeki değişmeler nedeniyle dolaşım hızının sabit olmadığını, Keynes (1936) faiz oranlarındaki değişmeler nedeniyle paranın dolaşım hızının durağan olmadığını, Friedman (1959) kaynakların tam verimlilikle kullanılması ve para talebinin faiz oranına karşı duyarsız olması koşuluyla uzun dönemde paranın dolaşım hızının durağan olduğunu belirtmektedir1.

Paranın dolaşım hızının doğası belirlendikten sonra para talebi fonksiyonunun tahmin edilmesi üzerine yoğunlaşılmaktadır. Ireland (2010) ve Hossain (2012) faiz oranlarının; Frenkel (2010) ve Beckmann ve Kühl (2011) döviz kurunun; McKinnon (2010) ve Mansaray ve Swaray (2012) finansal gelişmelerin; Korhonen ve Mehrotra (2010) ve Dagher ve Kovanen (2011) para ikamesinin para talebi üzerindeki etkisini incelemektedir. Ayrıca, Kumar (2011) ve Kumar ve Rao (2012) para talebini belirleyen değişkenlerin ülkelere göre farklılık gösterdiğini ve evrensel bir para talebi fonksiyonunun başarısız olacağını belirtmektedir.

1 Bu çalışmalara ek olarak, Dreger ve Volters (2015), Belongia ve Ireland (2015) ve Mogliani ve Urga (2018) paranın dolaşım hızının istikrarlı olmadığı hipotezini destekleyerek küreselleşme ile birlikte yaygınlaşan özellikle faiz oranları, gelirler ve ücretler ile ilgili ekonomik belirsizliklerin bu istikrarı bozduğunu belirtmektedir. Buna karşın, Bahmani-Oskooee ve Gelan (2009), Baunto vd. (2011) ve Basher ve Fachin (2012) paranın dolaşım hızının istikrarlı olduğunu belirtmektedir. 
Gelişmekte olan ülkeler arasında yer alan Türkiye'de 1980'den itibaren iktisadi hakim paradigmanın değişerek finansal ve ekonomik liberalleşme yolunda önemli adımlar atılmaktadır. $\mathrm{Bu}$ dönüşüm sürecinde önemli değişimler olarak dikkat çeken finansal derinleşme ve çeşitlenme ile kronik yüksek enflasyon nedeniyle ortaya çıkan dolarizasyon süreci ekonomik ajanların gelir ve servetlerinin reel alım gücünü korumak amacıyla portföylerinde değeri istikrarlı aktiflere daha fazla yer vermelerine neden olmakta, bu durum para talebi fonksiyonunun istikrarını bozarak para politikasının etkinliğini azaltmaktadır ${ }^{2}$. Ayrıca, bu zamandan günümüze kadar gelen süreçte enflasyonist sürecin durağanlaşması, finansal entegrasyonun sağlanması ve para politikasının fiyat istikrarı ve finansal istikrar ile uyumlu bir şekilde sürdürülmesi nedenleriyle bu çalışmada Türkiye için para talebi fonksiyonunun ve paranın dolaşım hızının yeniden analiz edilmesi amaçlanmaktadır.

Bu çalışma beş bölümden oluşmaktadır. İkinci bölümde paranın dolaşım hızının doğası ve para talebi fonksiyonu ile ilgili literatür taraması yapılmakta, üçüncü bölümde paranın dolaşım hızının ve para talebi fonksiyonunun ekonomik ve ekonometrik çerçevesi ve değişkenler arasındaki ilişkilerle ilgili önsel beklentiler belirtilmektedir. Daha sonra, paranın dolaşım hızının durağanlığı ve uzun dönemli hafızası incelenmekte, durağanlık testleri, varyans oranı testleri, uzun dönemli hafıza testleri ile paranın dolaşım hızının istikrarının, doğrusal olmayan gecikmesi dağıtılmış otoregresif model yöntemi ile para talebi fonksiyonunda yer alan değişkenler arasındaki ilişkilerinin belirlenmesi amaçlanmakta, son bölümde de bulgular değerlendirilerek bir senteze ulaşılmaya çalışılmaktadır.

\section{Literatür Taraması}

Paranın dolaşım hızındaki değişimleri açıklamaya yönelik çalışmalar çok eski dönemlere dayansa da, paranın dolaşım hızının doğası ile ilgili yapılan öncü çalışmalar arasında Friedman ve Schwartz (1963) tarafindan oluşturulan veri setini ve yöntemini kullanan Gould ve Nelson (1974) ve Stokes ve Neuburger (1979) çalışmaları gösterilmektedir. Friedman ve Schwartz (1963) 1868-1960 dönemini üç farklı döneme ayırarak ödeme araçlarının ve savaş koşullarının paranın dolaşım hızı üzerinde etkili olduğunu belirtmekte, aynı veri setini kullanan Gould ve Nelson (1974) ve Stokes ve Neuburger (1979) paranın dolaşım hızının doğasını inceleyerek farklı sonuçlara ulaşmaktadır. Gould ve Nelson (1974) paranın dolaşım hızının tesadüfi yürüyüş süreciyle iyi bir şekilde nitelendirilebileceğini ve tarihsel bir kaymanın istatistiksel olarak anlamlı olmadığını belirtmesine rağmen, Stokes ve Neuburger (1979) değişken varyans probleminden dolayı Gould ve Nelson tarafından bulunan sonuçlarını eleştirerek 1879-1940 döneminde paranın dolaşım hızının tesadüfi yürüyüşs süreci izlemediğini ve istatistiksel olarak anlamlı negatif trend bulunduğunu sıradan en küçük kareler yöntemiyle açıklamaktadır.

2 Dülger (2002) ve Algan ve Gencer (2011) yüksek enflasyon ve finansal deragülasyon olgularının Türkiye örneğinde paranın dolaşım hızı üzerinde etkili olduğunu ifade etmektedir. 
Para talebinin stokastik doğası ile ilgili öncü bu çalışmalardan sonra 1980'li yıllarda yaşanan enflasyonist süreçler ve merkez bankalarına fiyat istikrarı hedefinin yüklenmesi ile bağımsız kılınmaları nedeniyle para talebi fonksiyonun tahmini ile ilgili yapılan çalışmalar yaygınlaşmaktadır. İlgili çalışmalarda para talebinin istikrarlı olmasının ön koşulu olması nedeniyle paranın dolaşım hızının durağan olmasına önem atfedilmektedir. Paranın dolaşım hızının ve belirleyicilerinin birinci farklarının durağan süreç izlemesi nedeniyle geliştirilen farklı eşbütünleşme tekniklerinin ve Pesaran, Shin ve Smith (2001) tarafından geliştirilen ve serilerin sıfırıncı ve birinci dereceden durağan süreçler izlemesi durumunda bile eşbütünleşme testine ve kısa ve uzun dönem analizine olanak veren ARDL sınır testinin yaygın olarak kullanıldığı görülmektedir. Hye (2009) Pakistan için, Kumar vd. (2010) Nijerya için, Belke ve Czudaj (2010) Avrupa Birliği için, Wang (2010) Amerika Birleşik Devletleri için, Suliman ve Dafaalla (2011) Sudan için, Kumar ve Webber (2013) Avustralya için, Cho ve Ramirez (2016) Güney Kore için, Ahad (2017) Pakistan için, Hien ve Long (2019) Vietnam için yaptıkları çalışmalarda genel olarak parasal büyüklükle, gelir düzeyi, döviz kuru ve faiz oranı arasında eşbütünleşik ilişki bulunduğu sonucuna ulaşmaktadır. Rao ve Kumar (2011) Gregory ve Hansen eşbütünleşme testi ve tam modifie edilmiş EKK yöntemi ile ABD için $M_{1}$ para talebi fonksiyonunun trend içeren modelde istikrarlı olduğu, Kumar ve Webber (2013) ise aynı yöntemler çerçevesinde Avustralya ve Yeni Zelanda için $M_{1}$ para talebi fonksiyonunun istikrarlı olmadığını ve Kumar vd. (2013) Nijerya için $M_{l}$ para talebi fonksiyonunun istikrarlı olduğunu göstermektedir. Foresti ve Napolitano (2013) panel veri, Pedroni panel eşbütünleşme ve dinamik EKK yöntemlerini kullanarak G7 ülkeleri ile Avustralya ve İsviçre için para talebi fonksiyonunun istikrarlı olduğunu, para talebinin gelir, döviz kuru ve faiz esnekliklerinin sırasıyla pozitif, pozitif ve negatif olduğunu belirtmektedir. Iyoboyi ve Pedro (2013) ise Nijerya için para talebi fonksiyonu tahmini parametrelerinin istikrarlı olduğunu ve para talebinin gelir esnekliğinin pozitif, faiz esnekliğinin negatif olduğunu belirtmektedir.

Türkiye ile ilgili yapılan çalışmalarda, Bahmani-Oskooee ve Karacal (2006) $M_{l}$ ile enflasyon oranı ve döviz kuru arasında negatif yönlü, $M_{2}$ ile döviz kuru arasında pozitif yönlü istatistiksel olarak anlamlı ilişkiler bulmakta ve para talebi fonksiyonu tahminlerinin Cusum ve CusumQ testleri ile istikrarlı olduğu göstermektedir. Özcan ve Arı (2013) Johansen eşbütünleşme tekniği ile para talebinin istikrarlı olmadığını ve para talebinin gelir, faiz ve döviz kuru esnekliklerinin sirasıyla pozitif, negatif ve pozitif olduklarını ve beklentilerle uyumlu olduklarını belirtmektedir. Yılancı (2012), Gencer ve Arısoy (2013), Özçalık (2014) ve Atgür ve Altay (2015) ise para talebi fonksiyonunu ARDL sinır testi modeli ile analiz etmektedir. Yılancı (2012) kayan pencereler sınır testi ile para talebi fonksiyonunun istikrarlı olmadığını, Özçalık (2014) para talebi fonksiyonunun istikrarlı olmadığını ve para talebi gelir ve faiz oranı esnekliklerinin pozitif olduğunu, Gencer ve Arısoy (2013) zamanla değişen katsayılar yöntemi yardımıyla para talebinin faiz oranı ve enflasyon oranı esnekliklerinin negatif, gelir ve döviz kuru esnekliklerinin ise pozitif olduğunu, Atgür ve Altay (2015) Türkiye için kısa ve 
uzun dönemde para talebinin istikrarlı olmadığını ve para talebi ile gelir düzeyi, faiz oranı ve enflasyon arasında anlamlı bir ilişki bulunmadığını belirtmektedir.

\section{Teorik Çerçeve}

\section{Paranın Dolaşım Hızı}

Paranın dolaşım hızı paranın ortalama olarak belirli bir süre içerisinde ne kadar el değiştirdiğini belirtmektedir. Toplam gelir ve toplam işlemlerin sabit bir ilişki içerisinde olduğu zımnı olarak varsayılırsa, paranın işlem dolaşım hızı veya paranın gelir dolaşım hızı kavramları birbirlerinin yerine kullanılsa da, ara mal işlemlerinin ve finansal işlemlerin yoğunlaşması ve kredi talebi nedeniyle bu iki kavramın birbirinden farklılaştığı görülmektedir. Jonung (2018) paranın işlem dolaşım hızının daha istikrarlı olduğunu belirtse de, Türkiye için enflasyon ve para ikame olgusunun güçlü olması, finansal derinliğin ve çeşitliliğin ve kredi talebinin yeterli olmamasından ötürü daha istikrarlı olması nedeniyle bu çalışmada paranın gelir dolaşım hızının kullanılması uygun görülmektedir. Bu çalışmada paranın dolaşım hızı olarak ifade edilen bütün kavramlar paranın gelir dolaşım hızını belirtmekte olup, paranın dolaşım hızı toplam parasal gelirin $\left(Y_{p}\right)$ para arzına $\left(M_{d}\right)$ oranı olarak hesaplanmaktadır ${ }^{3}$ (Ball, 2017).

$V=\left(Y_{p}\right) / M_{d}$

Düzmece regresyon sorunundan kaçınmak amacıyla, paranın dolaşım hızının durağanlığının incelenmesi gerekmektedir. Bu çalışmada paranın dolaşım hızının durağanlığı birim kök testleri, varyans oranı testleri ve kesirli bütünleşme modelleri olmak üzere üç temel yöntem ile detaylıca araştırılmaktadır. İlk olarak, birim kök testleri $\rho=0$ boş hipotezinin sınanmasına dayanmakta ve literatürde durağanlık sınamaları içerisinde en sık kullanılan yöntem olmaktadir.

$\Delta V_{t}=\alpha+\rho V_{t-1}+\sum_{i=1}^{k} \Delta V_{t-i}+\epsilon_{t}$

Kısıtlı veri setleriyle çalışılması durumunda geleneksel birim köklerinin sapmalı sonuçlar vermesi, zaman içerisinde paranın dolaşım hızını etkileyen değişkenlerin farklılık göstermesi ve veri derlemede yaşanan zorluklar geleneksel birim kök testlerine nispeten daha güvenilir olan yapısal kırılmalı birim kök testleri ile paranın dolaşım hızının durağanlığının sınanmasını gerektirmektedir. Son dönemlerde finansal yenilikler ve entegrasyon, para ikamesi gibi nedenlerle döviz kurunun doğrusal bir yapı arz etmediğini varsayılırsa, bu çerçevede geliştirilen doğrusal olmayan modeller, en basit haliyle, paranın dolaşım hızının şeklinde bir süreci izlediği varsayımı altında $\theta=0$ boş hipotezinin sınanması esasına dayanmaktadır.

$V_{t}=\alpha+\tau\left[1-\exp \left(-\theta V_{t-1}^{2}\right)\right] V_{t-1}+\epsilon_{t}$ 
Bununla birlikte, söz konusu boş hipotezinin $\tau$ katsayısına ilişkin herhangi bir bilgi içermemesi nedeniyle, Taylor açılımı yöntemiyle eşitlik yeniden yazılarak $\delta=0$ boş hipotezi sinanmaktadir.

$\Delta V_{t}=\delta V_{t-1}^{3}+\epsilon_{t}, \quad \delta=\beta \theta$

Varyans oranı testlerinde paranın dolaşım hızının k’ıncı sıradan fark varyansının, birinci sıradan fark varyansınının k katı olması paranın dolaşım hızının tesadüfi yürüyüş sürecine sahip olduğu anlamına gelmektedir.

$\operatorname{Var}\left(V_{t}-V_{t-k}\right)=k \cdot \operatorname{Var}\left(V_{t}-V_{t-1}\right)$

Buna $V R=(1 / k)$. $\operatorname{Var}\left(V_{t^{-}} V_{t-k}\right) / \operatorname{Var}\left(V_{t^{-}} V_{t-1}\right)$ göre, şeklinde yeniden düzenlenebilecek boş hipotezde varyans oranının $(V R)$ birden küçük olması paranın dolaşım hızının durağan olduğuna ve ortalamaya yöneldiğine işaret ederken, bire eşit olması paranın dolaşım hızının tesadüfi yürüyüş süreci izlediği anlamına gelmektedir. Birden büyük olması ise, paranın dolaşım hızının ortalamaya yönelmeme hususunda israrcı olduğunu göstermektedir.

Üçüncü yöntem olarak Granger ve Joyeux (1980) tarafından geliştirilen otoregresif kesirli bütünleşik hareketli ortalama (Autoregressive Fractional Integrated Moving Average, ARFIMA) modeli kullanılmaktadır. Paranın dolaşım hızı serisi için ARFIMA (p, d, r) modelinde d bütünleşme derecesini, L gecikme operatörünü, $\Phi(L)$ ve $\Theta(L)$ gecikme polinomlarını, $\mu$ ise ortalamay1 göstermektedir.

$\Phi(L)(1-L)^{d}\left(q_{t}-\mu\right)=\Theta(L) \epsilon_{t}, \quad \epsilon_{t}=$ i.i.d. $\left(0, \sigma^{2}\right)$

Tablo 1

d Parametresi ile Paranın Dolaşım Hızı Arasındaki İlişki

\begin{tabular}{ll}
\hline $\mathbf{d}$ & Paranın Dolaşım Hızı \\
\hline$\geq 1.0$ & Paranın dolaşım hızı durağan değildir. \\
$0.5-1.0$ & Sapmalar ortalamaya yönelmektedir ancak durağan değildir. \\
$0-0.5$ & Sapmalar ortalamaya yönelmektedir ve uzun dönemde durağandır. \\
0 & Sapmalar durağandır ve ortalamaya yönelmektedir. Paranın dolaşım hızı durağandır. \\
\hline
\end{tabular}

Kaynak: Villeneuve ve Handa (2006)

\section{Para Talebi Fonksiyonu}

Para talebi fonksiyonu ile paranın dolaşım hızını etkileyen değişkenlerin belirlenmesine bütün iktisat akımları önem atfetmektedir. Neoklasik iktisat akımının öncüleri arasında yer alan Fisher (1911) ve Pigou (1917) tarafindan geliştirilen Klasik Miktar Teorisi'ne göre para talebi gelirin bir fonksiyonu olarak ifade edilmekte, kısa dönemde gelir ve paranın dolaşım hızı sabit kabul edilerek para arzı ve fiyatlar genel düzeyinin aynı oranda ve yönde değişeceğini belirtilmektedir.

$V=(p * Y) / M$ 
$V$ paranın dolaşım hızını, $P$ fiyatlar genel seviyesini, $V$ reel üretim düzeyini ve $M$ para arzını göstermektedir. Keynes (1936) ortaya attığı Likitide Tercihi Teorisi ile paranın dolaşım hızının istikrarlı olmadığını, faiz oranına bağlı olarak değişebileceğini göstermektedir. Keynesyen iktisat akımında paranın diğer finansal aktifleri ikame edebilmesi ve bu nedenle para talebinin faiz esnekliğinin yüksek olduğu ortaya konmaktadır.

$V=p * Y / M^{\alpha}(i, Y)$

(8) numaralı denklemde para talebinin $\left(M^{d}\right)$ faiz oranının $(i)$ ve gelir düzeyinin $(V)$ bir fonksiyonu olduğu belirtilmektedir. Monetarist iktisat akımı ile ismi özdeşleşen Friedman (1959) geliştirdiği Modern Miktar Teorisi ile paranın özelliklerine aktif bir değer olma ve servet saklama aracı olmasını eklemekte, daimi gelir olarak adlandırdığı geniş kapsamlı uzun vadeli bir gelir kavramıyla serveti tanımlayarak Klasik Miktar Teorisi'nin daha genişletilmiş bir haline ulaşmaktadır. Monetarist iktisat akımında paranın gelir ve servet etkisine önem verilmekte, para tüm finansal ve reel aktiflerin ikamesi olarak görüldüğü için para talebinin faiz esnekliğinin düşük olduğu belirtilmektedir.

$V=1 / f\left(Y_{p}, i_{e}, i_{b},(1 / p * d p / d z), W_{h}\right)=p * Y / M^{d}$

$Y_{p}, i_{e}, i_{b},\left(1 / p^{*} d p / d z\right), W_{h}$ sirasiyla sürekli geliri, hisse senedinin ve tahvilin beklenen getirisini, enflasyon beklentisini ve serveti göstermektedir. Goldfeld (1973) çalışmasında enflasyon beklentisi, faiz oranı ve reel gelir değişkenlerinin para talebi ve dolayısıyla paranın dolaşım hızını nasıl belirlediğini göstermekte, bütün değişkenler logaritmik formda belirtilerek regresyon doğrusallaştırılmaktadır.

$V_{t}=\left(1-\theta_{1}\right) Y_{t}+\theta_{2} r_{t}+\theta_{3} p_{t}^{e}+\varepsilon_{t}$

(10) numaralı denklemde $r_{t}$ piyasa faiz oranını, $p_{t}{ }_{t}$ ise enflasyon beklentisini ifade etmektedir. McKinnon (1996) paranın dolaşım hızı üzerinde doğrudan veya dolaylı olarak etkili olan para ikamesi olgusunun özellikle Türkiye gibi gelişmekte olan ülkelerin 1990'lı y1llarda yaşadığı yüksek enflasyonist süreçler nedeniyle ekonomik ajanların reel alım güçlerini koruyabilmek için portföylerini çeşitlendirdiğini ve paranın dolaşım hızını değiştirebildiğini belirtmekte, yabancı aktiflerin nominal getirisinin de para ikamesi olgusuna benzer bir şekilde ekonomik ajanların portföylerinin kompozisyonunun değişmesi ile paranın dolaşım hızı üzerinde etkili olduğunu vurgulamaktadır.

$V_{t}=f\left(Y_{t}, i_{t}, \varphi_{t},\left(i_{t}^{f}+\varphi_{t}\right),\left(m_{t-j}-p_{t-j}\right)\right)+e_{t}$

$Y_{t}, i_{t}, \varphi_{t},\left(i_{t}^{f}+\varphi_{t}\right)$ ve $\left(m_{t}-p_{t}\right)$ sırasıyla reel gayri safi yurt içi hasılayı, faiz oranını, milli paranın değer kaybı oranını, yabancı aktiflerin getiri oranını ve para talebini ifade etmektedir. Bu çalışmada, McKinnon (1996) tarafından önerilen para talebi fonksiyonu baz alınmakla birlikte, paranın dolaşım hızını belirlemek için reel gayri safi yurt içi hasıla, Türk Lirası 
cinsinden mevduat faiz oranı ve milli paranın değer kaybını oranını ve yabancı aktiflerin getiri oranını temsilen reel efektif döviz kuru değişken olarak belirlenmektedir ${ }^{4}$. Türkiye'de yüksek enflasyonist süreçlerde para ikamesi olgusunun önem kazanması ve aynı dönemde para ikamesi ile döviz kuru arasındaki yüksek korelasyonlu ilişki nedeniyle reel döviz kuru aynı zamanda para ikamesi olgusunun etkisini de yansıtmaktadır (Taşçı, Darıcı ve Erbaykal, 2009). Tahmin edilen modelde kullanılan bağımlı ve açıklayıcı değişkenler son haliyle Lee ve Hwang (2001) tarafindan önerilen modele benzemektedir.

$\mathrm{Bu}$ değişkenlerin katsayıları literatürdeki çalışmalar doğrultusunda önsel olarak tahmin edildiğinde, para talebinin gelir esnekliği sıfır ile bir arasında ise, gelirin para talebinden daha fazla artması nedeniyle paranın dolaşım hızının arttığını söylemek mümkün olmakta, ayrıca para arzının bir lüks mal olduğu kabul edilerek uzun dönemli para talebinin gelir esnekliğinin birden büyük olması beklenmektedir. Tasarruf ve Türk Lirası vadeli mevduat hesaplarının dikkate alındığı yurt içi faiz oranı ile para tutmanın firsat maliyeti ve para talebinin gelir esnekliği arasındaki pozitif korelasyonlu ilişki nedeniyle faiz oranının esnekliğinin pozitif olması beklenmektedir. Milli paranın hem döviz kuru hem de enflasyon oranı aracılığıyla değer kaybını gösteren değişken olarak alınan reel döviz kurunun paranın dolaşım hızı üzerine etkisi literatürde tartı̧̧ılmaktadır. Arize, Malindretos ve Shwiff (1999) milli paranın değer kaybettikçe ekonomik ajanların ellerinde tuttukları yabancı varlıkların değerlenmesi kanalıyla servetin ve para talebinin artması ile dolaşım hızı esnekliğinin pozitif olacağını, Lee ve Hwang (2001) milli paranın değer kaybetmesinin dış ticaret dengesini ve reel gelirleri negatif etkilemesi kanalıyla para talebinin düşerek paranın dolaşım hızı esnekliğinin negatif olacağını belirtmektedir.

\section{Ekonometrik Yöntem}

Ekonomi literatüründe tahmin edilen para talebi fonksiyonlarının ekonometrik olarak incelenmesi için sıklıkla kullanılan yöntemler arasında yer alan etki-tepki analizlerinin tipik olarak değişkenlerin dinamik süreçlerini görmezden gelmesi ve eş anlı ilişkilere odaklanması; nedensellik çalışmalarının dinamik koşullara fazla önem vererek cari etkileri analiz etmede ve diğer ilişkili değişkenlerin etkilerini açıklamada yetersiz kalması nedeniyle değişkenlerin cari ve gecikmeli değerlerini de içeren genel bir fonksiyonel yapının belirlenmesi gerekmektedir 5 .

$\Delta Y_{t}=f\left(\left\{\Delta Y_{t-j}\right\}_{j=1}^{k},\left\{\Delta X_{t-j}\right\}_{j=1}^{k}, g_{t}, \omega\right)$

$\Delta Y_{t}$ sdsd bağımlı değişkenin vektörünü, $\Delta X_{t}$ açıklayıcı değişkenlerin vektörünü, $g_{t}$ bağım1 değişkenle ilişkili olabilecek diğer açıklayıcı değişkenlerin vektörünü, $\omega$ katsayılar vektörünü ifade etmekte, bu gösterim bütün değişkenlerin cari ve gecikmeli etkilerini içeren $\mathrm{AR}(\mathrm{k})$ 
sürecini ifade etmektedir6.

Küçük bir örneklem büyüklüğü ile daha tutarlı tahminler yapmaya olanak sağlaması ${ }^{7}$, modelin gecikme uzunluğunun tanımlandıktan sonra eşbütünleşme ilişkisinin en küçük kareler yöntemi (OLS) ile tahmin edilmesine izin vermesi, farklı dereceden eşbütünleşik serilerin analizini gerçekleştirmesi nedeniyle önceden herhangi bir ön test gerektirmemesinin analizlerde kolaylık sağlaması, modeldeki değişkenlerin zaman serisi özelliklerinden bağımsız olarak uzun süreli ilişkiler kurulabilmesi ve açıklayıcı değişkenlerin endojen olması durumunda da tutarlı sonuçlar verebilmesi ${ }^{8}$ ile kısa ve uzun dönem etkilerini eş anlı olarak ortaya koyması nedeniyle bu çalışmada ARDL yöntemi kullanılmakta, geliştirilen vektör hata düzeltme modeli aracılığıyla uzun dönem çarpan matrisi ve kısıtları belirlenmektedir.

$$
\begin{aligned}
& \Delta Z_{t}=\vartheta+\beth t+\theta Z_{t-1}+\sum_{j=1}^{s-1} \gamma_{i} \Delta Y_{t-j}+\sum_{j=1}^{s-1} \gamma_{i} \Delta X_{t-j}+\varepsilon_{t} \\
& \theta=\left[\begin{array}{ll}
\theta_{y y} & \theta_{y x} \\
\theta_{x y} & \theta_{x x}
\end{array}\right]
\end{aligned}
$$

$\Delta, \vartheta, \beth t, Z_{t}, Y_{t}, X_{t}$ ve $\varepsilon_{t}$ sırasıyla fark operatörünü, sabit terim vektörünü, zaman trendini, bağımlı ve açıklayıcı değişkenler ile hata terimi vektörlerini belirtmektedir. Ayrıca, (14) nolu denklemde gösterilen matrisin diyagonal bileşenlerinin kısıtsız olması farklı dereceden bütünleşik serilerin seçilmesine olanak sağlamaktadır. $\theta_{y y}>0$ olması bağımlı değişkenin birinci dereceden bütünleşik olduğunu (I(1)), $\theta_{y y}<0$ olması ise bağımlı değişkenin sıfırıncı dereceden bütünleşik $(\mathrm{I}(0))$ olduğunu ifade etmektedir.

ARDL modeli değişkenler arasındaki kısa ve uzun dönem simetrilerini dikkate almakta ve doğrusal ilişkiyi tespit etmektedir. Shin, Yu vd. (2014) değişkenler arasındaki asimetrik ve doğrusal olmayan ilişkileri dikkate alarak doğrusal olmayan ARDL (NARDL) modelleme yaklaşımını geliştirmekte, böylece değişkenler arasındaki kısa ve uzun dönem asimetrik ilişki üzerine odaklanılarak açıklayıcı değişkenlerde meydana gelen negatif ve pozitif değişmelerin bağımlı değişken üzerinde oluşturduğu etkiler belirlenmektedir. Mevduat faiz oranı ve reel efektif döviz kuru değişkenlerinin zaman içerisinde asimetrik ve doğrusal olmayan bir seyirde olduğu göz önünde bulundurularak, bu değişkenlerin pozitif ve negatif değişmelerinin ayrıştırılarak analiz edilmesi gerekmektedir'?.

$$
\gamma(\varphi) Y_{t}=\theta_{0}+\theta_{1} d_{t}+\beta(\varphi) X_{j t}+u_{t}
$$

Burada $\gamma(\varphi)=1-\sum_{j=1}^{\infty} \gamma \varphi^{j}, \beta(\varphi)=\sum_{m=1}^{\infty} \beta_{m} \varphi^{m},(\varphi)$ gecikme operatörünü ve $d_{t}$ deterministik değişkenleri belirtmektedir. Shin, Yu vd. (2014) tarafından yapılan çalışma çer-

9 Chuliá vd. (2010), Yu vd. (2013), Apergis ve Cooray (2015), Zhang vd. (2017), Hamzah ve Masih (2018) ve Oliver vd. (2019) faiz oranlarının, Delatte ve López-Villavicencio (2012), Bussiere (2013), Jammazi vd. (2015), Latheef ve Masih (2017), Bahmani-Oskooee ve Gelan (2019) ve Alsamara ve Mrabet (2019) döviz kurlarının asimetrik etkilerini inceleyen çalışmalar olarak literatürde yer almaktadır. 
çevesinde oluşturulan asimetrik eşbütünleşme regresyonu değişkenlerdeki negatif ve pozitif değişmeleri ve uzun dönem parametreleri ile ifade edilmektedir.

$$
\begin{aligned}
& Y_{t}=\beta^{+} X_{t}^{+}+\beta^{-} X_{t}^{-}+u_{t} \\
& X_{t}=X_{0}+X_{t}^{-}+X_{t}^{+}
\end{aligned}
$$

(17) nolu denklem $\operatorname{ARDL}(\mathrm{p}, \mathrm{q})$ modeliyle ilişkilendirildiğinde asimetrik hata düzeltme modeli (AECM) elde edilmektedir.

$$
\Delta Y_{t}=\rho Y_{t-1}+\vartheta^{+} X_{t-1}{ }^{+}+\vartheta^{-} X_{t-1}{ }^{-}+\sum_{i=1}^{p-1} \vartheta \Delta Y_{t-i}+\sum_{i=0}^{q}\left(\tau^{+} \Delta X_{t}^{+}+\tau^{-} \Delta X_{t}^{-}\right)+\varepsilon_{t}
$$

Burada $\vartheta^{+}=-p \beta^{+}, \vartheta^{-}=-p \beta^{-}, \tau^{+}=-\beta^{+} \vartheta_{i}+\omega_{2 i}$ ve $\tau^{-}=-\beta^{-} \vartheta_{i}+\omega_{2 i}$ olarak ifade edilmektedir. (11) numaralı denklemdeki değişkenler baz alınarak (18) numaralı denklem doğrusal ECM modeline kısa dönem ve uzun dönem asimetriler eklenerek genişletildiğinde NARDL modeli elde edilmektedir.

$$
\begin{aligned}
& V_{t}=\delta_{0}+\delta_{1} T+\delta_{2} V_{t-1}+\delta_{3} Y_{t-1}+\delta_{4}{ }^{-} i_{t-1}{ }^{-}+\delta_{4}{ }^{+} i_{t-1}{ }^{+}+\delta_{5}{ }^{-} \varphi_{t-1}{ }^{-}+\delta_{5}{ }^{+} \varphi_{t-1}{ }^{+}+\sum_{j=1}^{p-1} \delta_{6} \Delta V_{t-j}+ \\
& \sum_{j=0}^{q} \delta_{7} \Delta Y_{t-j}+\sum_{j=0}^{r} \delta_{8} \Delta i_{t-j}{ }^{-}+\sum_{j=0}^{s} \delta_{9} \Delta i_{t-j}{ }^{+}+\sum_{j=0}^{t} \delta_{10} \Delta \varphi_{t-j}{ }^{-}+\sum_{j=0}^{w} \delta_{11} \Delta \varphi_{t-i}{ }^{+}+\mu_{i}
\end{aligned}
$$

Bu denklem paranın dolaşım hızının geçmiş değerlerinden etkilendiğini ve onlarla açıklanabileceğini, böylece ekonomide oluşacak dışsal şokların etkilerini de yansıtacağını göstermektedir. Uzun vadeli esneklikler açıklayıcı değişkenlerin birinci gecikmelerinin katsayılarının bağımlı değişkenin birinci gecikmesinin katsayısına bölünmesi ile elde edilmektedir10.

Regresyon tahmin edildikten sonra Wald testi (F-istatistik) ile değişkenler arasındaki uzun vadeli ilişkinin düzeyi tahmin edilmekte, hesaplanan F istatistik değeri Narayan (2005) tablo değerleriyle karşılaştırılarak açılayıcı değişkenlerin eşbütünleşme seviyeleri belirlenmektedir. Hesaplanan $\mathrm{F}$ istatistik değeri alt kritik değerlerden küçükse $H_{0}$ önsavı kabul edilmekte ve değişkenler arasında eşbütünleşme olmadığı sonucuna varılmaktadır. Eğer $F$ istatistik değeri iki kritik değer arasında ise durum belirsiz olmakta, kritik değerlerden büyük olursa $H_{0}$ önsavı reddedilerek değişkenler arasında eşbütünleşme olduğu kabul edilmektedir. F testinin sonucunda değişkenlerin eşbütünleşik olması, uzun dönem katsayılarının ve kısa dönemli hata düzeltme katsayısının tahmin edilebilmesine olanak sağlamaktadır.

\section{Veri Seti ve Değişkenler}

Çalışma kapsamında öncelikle uzun dönemde durağanlığı incelenen paranın dolaşım hızı 1970-2017 dönemine ait 48 yıllık gözlemden oluşmaktadır. Paranın dolaşım hızı $V=Y / M_{d}$

10 Gelirin, faiz oranındaki negatif ve pozitif değişimlerin ve döviz kurundaki negatif ve pozitif değişimlerin uzun dönemli esneklikleri sirasiyla $\delta_{3} / \delta_{2}, \delta_{4}{ }^{-} / \delta_{2}, \delta_{4}{ }^{+} / \delta_{2}, \delta_{5}{ }^{-} / \delta_{2}, \delta_{5}{ }^{+} / \delta_{2}$ olarak ifade edilmektedir. 
formülüyle hesaplanmış olup burada $V$ paranın dolaşım hızını, $Y$ ve $M^{d}$ ise sırasıyla Türkiye için nominal gayri safi yurt içi hasılayı ve $M_{2}$ parasal büyüklüğünü ifade etmektedir ${ }^{11}$. Daha sonra, paranın dolaşım hızını etkileyen değişkenler olarak reel gayri safi yurt içi hasıla12, reel efektif döviz kuru ve tasarruf mevduatları ile Türk Lirası cinsinden mevduat faiz oran 13 için veri tabanlarından 1970-2017 dönemini kapsayan 48 yıllık veri derlenmektedir14. Reel gayri safi milli hasıla verileri dolar cinsinden cari fiyatlarla belirlenen nominal gayri safi milli haslla verilerinin deflate edilmesiyle hesaplanmaktadır. Reel döviz kuru $Q=S . P * / P$ formülüyle hesaplanmış olup burada $S, 1 \mathrm{ABD}$ dolarının Türk lirası karşıllğını gösteren nominal döviz kurunu, $P$ ve $P^{*}$ ise, sırasıyla, Türkiye ve ABD'ye ilişkin tüketici fiyatlarını göstermektedir. Veriler derlenirken Tablo 2'de belirtiler veri tabanları kullanılmakta, farklı veri tabanlarından derlenen verilerin birbirleriyle uyumlu oldukları kontrol edilmektedir.

Tablo 2

Çalışmada Kullanılan Veri Tabanları

\begin{tabular}{ll}
\hline Değişkenler & Veri Tabanları \\
\hline $\boldsymbol{V}_{\boldsymbol{t}}$ & TÜİK, EVDS \\
$\boldsymbol{Y}_{\boldsymbol{t}}$ & WB, IFS, TÜIKK \\
$\boldsymbol{i}_{\boldsymbol{t}}$ & TÜİK, EVDS \\
$\boldsymbol{\varphi}_{\boldsymbol{t}}$ & TÜIKK, EVDS, BLS \\
\hline
\end{tabular}

Logaritmik formda ifade edilen bütün değiş̧kenlerin zaman içerisindeki değişimleri Grafik 1'de gösterilmektedir. Buna göre, 2000'li yılların ortalarından itibaren Türk Liras1 cinsinden mevduat faiz oranlarındaki değişimlere paralel olarak paranın dolaşım hızının yavaşladığı, reel efektif döviz kurunun dalgalı bir seyir gösterdiği ve reel gayri safi yurt içi hasılanın artan trendi dikkat çekmektedir. Ayrıca, mevduat faiz oranı ve reel efektif döviz kuru değişkenlerinin zaman içerisinde asimetrik ve doğrusal olmayan bir seyirde olduğu söylenebilmektedir.

\section{Ekonometrik Bulgular}

$11 M_{2}$ parasal büyüklüğü nakit para, vadesiz mevduat, çekler, tasarruf ve kısa dönem vadeli mevduatların toplamı olarak ifade edilmektedir. Narayan vd. (2009), Mohammad, Wasti, Lal ve Hussain (2009), Ogunmuyiwa ve Ekone (2010), Sichei ve Kamau (2012), Nchor ve Adamec (2016), Sianturi vd. (2017) ve Bahmani-Oskooee vd. (2017) literatürde $M_{2}$ parasal büyüklüğünü içeren çalışmalar arasında yer almaktadır.

12 Gayri safi yurt içi hasıla verileri resmen 1998 yılında yayınlanmaya başlanmasına rağmen, gayri safi milli hasıla serisi ve yerleşik yabancıların mevduat büyüklükleri sayesinde tahmini olarak 1970 yılına kadar götürülmekte, bu oluşturulan gayri safi yurt içi hasıla verisinin uluslararası veri tabanlarında (IMF, WB) yayınlanan verilerle tutarlı olduğu görülmektedir.

13 Türkiye'de tasarruf sahiplerinin genellikle 1-3 ay vadeli mevduatları seçtikleri dikkate alınarak, TL cinsinden 3 aya kadar vadeli mevduatların ağırlıklı ortalama faiz oranları ortalamaları dikkate alınmaktadır. Bu veriye 1987 yılından itibaren erişilebilmesi nedeniyle, 1970-1987 yılları arasında tasarruf mevduat faiz oranı dikkate alınmaktadır.

14 Literatürde çeyrek dönemlik veri setleri ile oluşturulan çalışmalar dikkat çekse de, Türkiye İstatistik Kurumu (TÜİK) ve Dünya Bankası (WB) veri tabanları baz alınarak yıllık frekansta bir veri seti tercih edilmektedir. 
Durağanlık testlerinden önce Grafik 1 incelendiğinde, 2000'li yılların ortalarından itibaren paranın dolaşım hızının düşmesi ve $V_{t}$ serisinin durağan olmaması dikkat çekmektedir. Bununla birlikte, $V_{t}$ serisinin korelogramı incelendiğinde, içsel bağıntı fonksiyonunun yavaş bir şekilde azaldığı, herhangi bir şokun $V_{t}$ serisi üzerindeki etkisinin kaybolmasının uzun zaman aldığı görülmekte, bu durum $V_{t}$ serisinin durağan olmama olasılığını artırmaktadır.

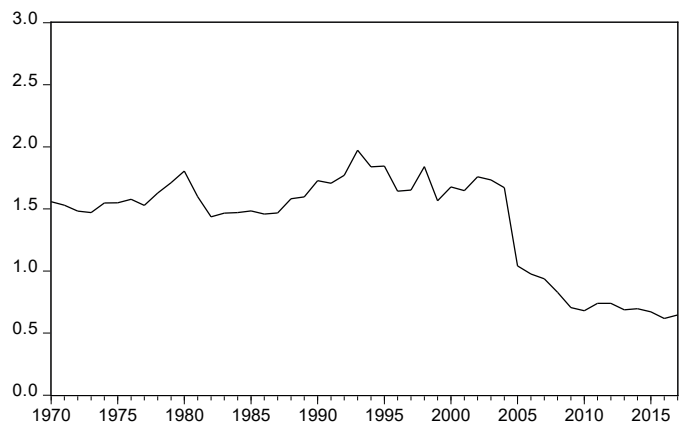

(a) Paranın Dolaşım Hızı $\left(V_{t}\right)$

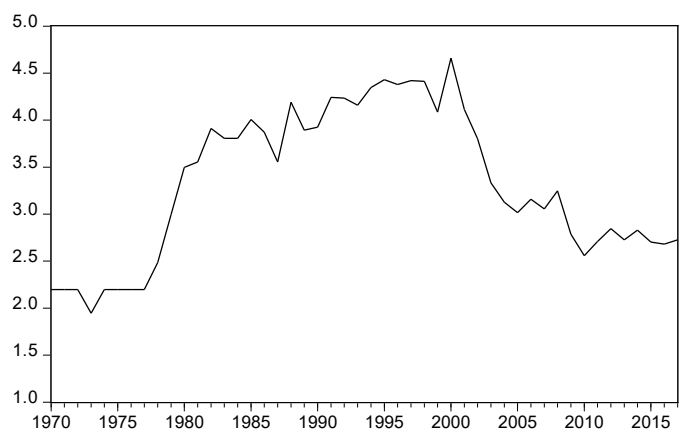

(c) Mevduat Faiz Oranı $\left(i_{t}\right)$

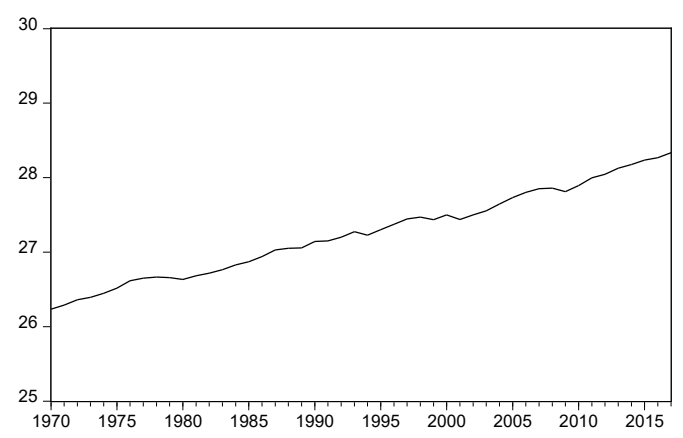

(b) Reel Gayri Safi Yurt İçi Hasıla $\left(Y_{t}\right)$

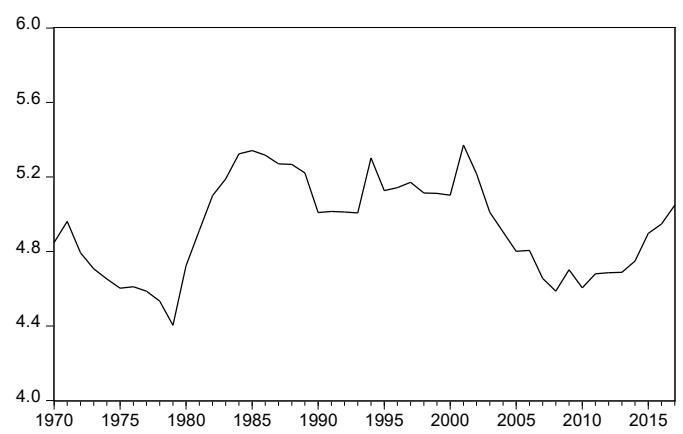

(d) Reel Efektif Döviz Kuru $\left(\varphi_{t}\right)$

Grafik 1. Değişkenlerin zaman içindeki seyri

Tablo 3

Paranın Dolaşım Hızının İçsel Bă̆ıntı Fonksiyonu

\begin{tabular}{lcccccccc}
\hline $\mathbf{k}$ & $\begin{array}{c}\text { İçsel } \\
\text { Bağıntı }\end{array}$ & $\mathbf{Q}$ İst. & Olassılık & $\mathbf{k}$ & $\begin{array}{c}\text { İçsel } \\
\text { Bağıntı }\end{array}$ & Q İst. & Olasılık \\
$\mathbf{1}$ & 0.910 & 42.32 & 0.00 & 6 & 0.433 & 153.88 & 0.00 \\
$\mathbf{2}$ & 0.817 & 77.12 & 0.00 & 7 & 0.331 & 160.30 & 0.00 \\
$\mathbf{3}$ & 0.723 & 105.02 & 0.00 & 8 & 0.243 & 163.85 & 0.00 \\
$\mathbf{4}$ & 0.635 & 127.04 & 0.00 & 9 & 0.157 & 165.36 & 0.00 \\
$\mathbf{5}$ & 0.538 & 143.18 & 0.00 & 10 & 0.064 & 165.62 & 0.00
\end{tabular}


Notlar: (1) k gecikme sayısını; Q istatistiği ise k'ıncı gecikmeye kadar içsel bağıntının olmadığına dair boş hipotezin sınanmasına yönelik olarak Ljung ve Box (1978) tarafından geliştirilen test istatistiğini göstermektedir.

\section{Paranın Dolaşım Hızının Durağanlığının Sınanması}

\section{Geleneksel Birim Kök Testleri}

İlk olarak $V_{t}$ serisinin durağanlığı Dickey ve Fuller (1981) tarafından formüle edilen Genişletilmiş Dickey-Fuller (Augmented Dickey-Fuller, ADF) ve Elliott vd. (1996) tarafindan önerilen Dickey-Fuller Genelleştirilmiş En Küçük Kareler (Dickey-Fuller Generalized Least Squares, $D F-G L S$ ) birim kök testleri yardımıla incelenmektedir. Bu iki testte, optimal gecikme sayısı Lagranj Çarpanı (Lagrange Multiplier, LM) kriteri, ardından da genelden özele (General-to-Specific, GtoS) yöntemi ile değiştirilmiş Akaike bilgi kriteri (Modified Akaike Information Criterion, MAIC) yardımıyla belirlenmektedir. Her üç yönteme göre, ADF ve DF-GLS testi $V_{t}$ serisinin durağan olmadığına işaret etmektedir. Benzer şekilde, Phillips ve Perron (1988) tarafından geliştirilen Phillips-Perron (PP) ile Ng ve Perron (2001) tarafından formüle edilen Ng-Perron $(N P)$ testleri $V_{t}$ serisinin durağan olmadığını reddedememekte, Kwiatkowski vd. (1992) tarafindan geliştirilen Kwiatkowski-Phillips-Schmidt-Shin (KPSS) testi de durağan olduğunu kabul edememektedir15.

Tablo 4

Geleneksel Birim Kök Testi Sonuçları

\begin{tabular}{|c|c|c|c|}
\hline \multicolumn{2}{|l|}{ Testler } & Sabit & Sabit ve Trend \\
\hline \multicolumn{2}{|c|}{$\mathbf{A D F}_{\mathrm{LM}, \mathrm{GtoS}, \mathrm{MAIC}}$} & $-0.361(0)$ & $-1.416(0)$ \\
\hline \multicolumn{2}{|c|}{ DF-GLS ${ }_{\mathrm{LM}, \text { GtoS, MAIC }}$} & $-0.342(0)$ & $-1.350(0)$ \\
\hline \multicolumn{2}{|c|}{$\mathbf{P P}_{\mathrm{MAIC}}$} & $-0.382(0)$ & $-1.440(0)$ \\
\hline \multirow{2}{*}{$\mathbf{N P}_{\text {MAIC }}$} & $\mathbf{M Z}_{\mathrm{a}}$ & $-0.725(0)$ & $-3,520(0)$ \\
\hline & $\mathbf{M Z}_{\mathrm{t}}$ & $-0.315(0)$ & $-1,247(0)$ \\
\hline \multicolumn{2}{|c|}{$\mathbf{K P S S}_{\text {MAIC }}$} & $23.40(0)^{*}$ & $5.189(0)^{*}$ \\
\hline
\end{tabular}

Notlar: (1) Kritik değerler ADF ve PP testleri için Fuller (1976), DF-GLS testi için Elliott vd. (1996), NP testleri için Ng ve Perron (2001), KPSS testi için ise Kwiatkowski vd. (1992) tarafindan hazırlanan tablo değerlerine ve gözlem sayısına uygun olarak alınmaktadır. (2) ADF ve PP testlerinde \% 1 ve \% 5 anlamlılık düzeylerinde kritik değerler sabit terim içeren modeller için, sırasıyla, -3.578 ve -2.925 iken, sabit ile birlikte trend içeren modeller için -4.166 ve -3.509 'dur. Söz konusu kritik değerler, sırasıyla, DF-GLS testi için -2.615 ve -1.948 ile -3.770 ve $3.190 ; \mathrm{NP} / \mathrm{MZ}_{\mathrm{a}}$ için -13.80 ve -8.10 ile -23.80 ve $-17.30 ; \mathrm{NP} / \mathrm{MZ}_{\mathrm{t}}$ için -2.58 ve -1.98 ile -3.42 ve -2.91 ; KPSS testi için 0.739 ve 0.463 ile 0.216 ve 0.146 'dır. (3) PP, NP ve KPSS testlerinde GLS-detrended prosedürü kullanılmaktadır. (4) Parantez içi değerler optimal gecikme sayısını temsil etmektedir. Maksimum gecikme sayısı 6 olarak alınmaktadır. (5) * işareti boş hipotezin \% 1 anlamlılık düzeyinde reddedildiğini göstermektedir.

\section{Yapısal Kırılma İçeren Birim Kök Testleri}

Geleneksel birim kök testleri, $V_{t}$ serisinin durağan olmadığına işaret etmektedir. Bununla

15 KPSS testinde diğer birim kök testlerin aksine, $H_{0}$ hipotezinde serinin durağan olduğu, $H_{l}$ hipotezinde ise serinin durağan olmadığı ifade edilmektedir. 
birlikte, serinin ele alınan dönemde yapısal kırılmalara maruz kalabilmesi, geleneksel birim kök testi sonuçlarını şüpheli hale getirmektedir. Bu nedenle, $V_{t}$ serisinin durağanlığı, yapısal kırılmaların varlığını göz önünde bulunduran birim kök testleri yardımıyla üç ayrı grupta tekrar incelenmektedir.

İlk grupta, temelleri Perron (1989) tarafindan ortaya atılan teste dayanmakla birlikte yap1sal kırılma dönemlerinin içsel olarak tespit edilebildiği Perron ve Vogelsang (1992), Clemente vd. (1998) ve Perron (1997) tarafından geliştirilen testlere başvurulmaktadır. Bu testlerden Perron-Vogelsang $(P V)$ ve Perron testleri tek bir kırılmanın varlığına izin verirken, Clemente-Montanes-Reyes $(C M R)$ testi ise iki kırılmanın incelenmesine imkân tanımaktadır. Tablo 5'de yer alan test sonuçlarından, tahmin edilen kırılma dönemlerinin Grafik 1 ile uyumlu olduğu görülmektedir. Bununla birlikte, PV ve CMR testleri hem anlık hem kademeli uyarlama modellerinde, Perron testi ise kırılmalı kademeli uyarlama modelinde $V_{t}$ serisinin durağan olduğunu işaret etmekte, Perron testi trendde ve sabit ve trendde kırılmalı anlık ve kademeli uyarlama modellerinde $V_{t}$ serisinin durağan olmadığını göstermektedir.

Tablo 5

Perron Testine Dayalı Yapısal Kırılma İçeren Birim Kök Testi Sonuçları

\begin{tabular}{|c|c|c|c|c|}
\hline \multirow{3}{*}{ Testler } & \multicolumn{4}{|c|}{ Sabitte Kırılma } \\
\hline & \multicolumn{2}{|c|}{ Anlık Uyarlama } & \multicolumn{2}{|c|}{ Kademeli Uyarlama } \\
\hline & t İstatistiği & Kırılma Dönemleri & t İstatistiği & Kırılma Dönemleri \\
\hline PV & $-3.967(0)^{* *}$ & 2006 & $-6.075(0)^{*}$ & 2003 \\
\hline CMR & $-5.708(0)^{* *}$ & 1991, 2006 & $-7.593(1)^{*}$ & 1988,2003 \\
\hline \multirow[t]{2}{*}{ Perron } & & & $-6.617(0)^{*}$ & 2004 \\
\hline & \multicolumn{2}{|c|}{ Trendde Kırılma } & \multicolumn{2}{|c|}{ Sabit ve Trendde Kırılma } \\
\hline \multirow[t]{2}{*}{ Testler } & \multicolumn{2}{|c|}{ Anlık Uyarlama } & \multicolumn{2}{|c|}{ Kademeli Uyarlama } \\
\hline & t İstatistiği & Kırılma Dönemleri & t İstatistiği & Kırılma Dönemleri \\
\hline Perron & $-2.886(0)$ & 1999 & $-3.936(3)$ & 2004 \\
\hline
\end{tabular}

Notlar: (1) Söz konusu üç test, yapısal kırılma karşısındaki uyarlamaların anlık olarak gerçekleştiği toplamsal aykırı gözlem (additive outlier) modeli ile kademeli olarak gerçekleştiği yenilikçi aykırı gözlem (innovational outlier) modeli çerçevesinde uygulanmaktadır. (2) Kritik değerler; PV testi için Perron ve Vogelsang (1992), CMR testi için Clemente vd. (1998), Perron testi için ise Perron (1997) tarafından hazırlanan tablo değerine ve gözlem sayısına uygun olarak alınmaktadır. (3) PV testinde \% 1 ve \% 5 anlamlılık düzeylerinde kritik değerler, sabit terimdeki kırılma karşısında uyarlamanın anlık olduğu model için, sırasıyla -4.37 ve -3.56 , kademeli olduğu model için, sırasıyla -5.10 ve -4.27 'dir. CMR testinde sabit terimdeki kırılma karşısında uyarlamanın gerek anlık gerekse kademeli olduğu modellerin her ikisi için söz konusu kritik değerler, sırasıyla -5.96 ve -5.49'dur. Perron testinde ise kritik değerler sabit terimdeki kırılma karşısında uyarlamanın kademeli olduğu model için, sırasıyla -5.15 ve -4.64; trenddeki kırılma karşısında uyarlamanın anlık olduğu model için, sırasıyla -4.69 ve -4.09 ; sabit terim ile trendin her ikisindeki kırılma karşısında uyarlamanın kademeli olduğu model için de -5.71 ve -5.16 'dır. (4) PV ve CMR testlerine konu olan modeller sadece sabit terimi, Perron testi ise sabit terim ile birlikte trendi içermektedir. (5) Parantez içi değerler, GtoS yaklaşımıyla belirlenen optimal gecikme sayısını temsil etmektedir. Maksimum gecikme sayısı 6 olarak alınmaktadır. (6) * ve ** işaretleri boş hipotezin \% 1 ve \% 5 anlamlılık düzeyinde reddedildiğini göstermektedir. (7) Kırpma (trimming) parametresi 0.15 olarak alınmaktadır.

İkinci grupta, yapısal kırılma dönemlerinin içsel olarak belirlendiği ve ADF testi temelinde Zivot ve Andrews (1992) tarafından formüle edilen Zivot-Andrews ( $Z A$ ) ile Lumsdaine ve 
Papell (1997) tarafindan ortaya atılan Lumdaine-Papell (LP) testleri uygulanmaktadır. Tek bir kırılmanın varlığını dikkate alan ZA testi ile iki kırılmaya imkan tanıyan LP testi sonuçlarına göre, sabitte ve sabit ve trendde kırılmanın söz konusu olması durumunda $V_{t}$ serisi durağan bir görünüm sergilemektedir. Yalnızca trendde kırılma söz konusu olduğunda ise her iki test de $V_{t}$ serisinin durağan olmadığını belirtmektedir.

Tablo 6

ADF Testine Dayalı Yapısal Kırılma İçeren Birim Kök Testi Sonuçları

\begin{tabular}{|c|c|c|c|c|c|c|}
\hline \multirow[b]{2}{*}{ Testler } & \multicolumn{2}{|c|}{ Sabitte Kırılma } & \multicolumn{2}{|c|}{ Trendde Kırılma } & \multicolumn{2}{|c|}{ Sabit ve Trendde Kırılma } \\
\hline & t İstatistiği & $\begin{array}{c}\text { Kırılma } \\
\text { Dönemleri }\end{array}$ & t İstatistiği & $\begin{array}{c}\text { Kırılma } \\
\text { Dönemleri }\end{array}$ & t İstatistiği & $\begin{array}{c}\text { Kırılma } \\
\text { Dönemleri }\end{array}$ \\
\hline $\mathrm{ZA}$ & $-6.678(0)^{*}$ & 2005 & $-3.089(0)$ & 1994 & $-5.788(0)^{*}$ & 2005 \\
\hline LP & $-7.818(0)^{*}$ & 1987, 2004 & $-4.772(0)$ & 2002,2008 & $-7.00(0)^{* *}$ & 1989,2004 \\
\hline
\end{tabular}

Notlar: (1) Kritik değerler ZA testi için Zivot ve Andrews (1992), LP testi için de Lumsdaine ve Papell (1997) tarafından hazırlanan tablo değerine ve gözlem sayısına uygun olarak alınmaktadır. (2) ZA testinde, söz konusu kritik değerlerler, sırasıyla, sabitte kırılma içeren model için -5.34 ve -4.93 ; trendde kırılma içeren model için -4.80 ve -4.42 ; sabit ve trendde kırılma içeren model için -5.57 ve -5.08 ' dir. LP testinde kritik değerler ise, sırasıyla, -6.74 ve -6.16 ; -7.19 ve -6.62 ; -7.19 ve -6.75 'tir. (3) Teste konu olan modeller, sabit terim ile birlikte trendi içermektedir. (4) Parantez içi değerler, GtoS yaklaşımıyla belirlenen optimal gecikme sayısını temsil etmektedir. Maksimum gecikme sayısı 6 olarak alınmaktadır. (5) * ve ** işareti, boş hipotezin \% 1 ve \% 5 anlamlılık düzeyinde reddedildiğini göstermektedir. (6) Kırpma parametresi 0.15 olarak alınmaktadır.

Üçüncü ve son grupta, $V_{t}$ serisinin durağanlığ 1 LM testine dayalı olarak Lee ve Strazicich (2004) tarafından geliştirilen bir kırılma içeren birim kök testi (LS1) ile yine Lee ve Strazicich tarafından (2003) tarafından formüle edilen iki kırılma içeren birim kök testi (LS2) kullanılarak analiz edilmektedir. LS1 ve LS2 testlerinde sabitte kırılma dikkate alındığında $V_{t}$ serisinin durağan olmadığ 1 , sabit ve trendde kırılma dikkate alındığında ise $V_{t}$ serisinin durağan olduğu ve birim kök içermediği görülmektedir.

Tablo 7

LM Testine Dayalı Yapısal Kırılma İçeren Birim Kök Testi Sonuçları

\begin{tabular}{lcccc}
\hline \multirow{2}{*}{ Testler } & \multicolumn{2}{c}{ Sabitte Kırılma } & \multicolumn{2}{c}{ Sabit ve Trendde Kırılma } \\
\cline { 2 - 5 } & Test İstatistiği & Kırılma Dönemi & Test İstatistiği & Kırılma Dönemi \\
\hline LS1 & $-2.144(5)$ & 1999 & $-5.795(6)^{*}$ & 2003 \\
LS2 & $-2.730(5)$ & 2000,2004 & $-7.583(6)^{*}$ & 1988,2003
\end{tabular}

Notlar: (1) Kritik değerler LS1 testi için Lee ve Strazicich (2004), LS2 testi için ise Lee ve Strazicich (2003) tarafından hazırlanan tablo değerlerine ve gözlem sayısına uygun olarak alınmaktadır. (2) LS1 testinde kritik değerler \% 1 ve \% 5 anlamlılık düzeylerinde sabitte kırılma içeren model için, sırasıyla, -4.084 ve -3.487; sabit ve trendde kırılma içeren model için -5.15 ve $-4.45^{\prime}$ tir. Söz konusu kritik değerler LS2 testinde ise, sırasıyla -4.896 ve -4.333 ile -6.691 ve -6.152 'dir. (3) Teste konu olan modeller sabit terim ile birlikte trendi içermektedir. (4) Parantez için değerler, GtoS yaklaşımıyla belirlenen optimal gecikme sayısını göstermektedir. Maksimum gecikme sayısı 6 olarak alınmaktadır. (5) Kırpma parametresi 0.15 olarak alınmaktadır. (6) * işareti boş hipotezlerin \% 1 anlamlılık düzeyinde reddedildiğini göstermektedir.

\section{Doğrusal Olmayan Birim Kök Testleri}

Geleneksel birim kök testleri ile yapısal kırılma içeren birim kök testleri uygulanırken, 
$V_{t}$ serisinin doğrusal olduğu varsayımı yapılmaktadır. Bu nedenle, doğrusal olmama durumunu (nonlinearity) dikkate alan Kapetanios vd. (2003) tarafindan üstel yumuşak geçişli otoregresif (Exponential Smooth Transition Autoregressive, ESTAR) modeline dayal1 olarak geliştirilen Kapetanios-Shin-Snell (KSS) ile Sollis (2009) tarafindan asimetrik üstel yumuşak geçişli otoregresif (Asymmetric Exponential Smooth Transition Autoregressive, AESTAR) modeli çerçevesinde formüle edilen birim kök testlerine başvurulmaktadır. Tablo 7'de özetlenen test sonuçlarına göre, gerek KSS gerekse Sollis testleri $V_{t}$ serisinin durağan olmadığını göstermektedir.

Tablo 8

Doğrusal Olmayan Birim Kök Testi Sonuçları

\begin{tabular}{lcc}
\hline Testler & Sabit & Sabit ve Trend \\
\hline KSS & $-0.753(0)$ & $-1.560(0)$ \\
Sollis & $2.108(0)$ & $1.612(0)$ \\
\hline
\end{tabular}

Notlar: (1) Kritik değerler KSS testi için Kapetanios vd. (2003), Sollis testi için de Sollis (2009) tarafından hazırlanan tablo değerlerine ve gözlem sayısına uygun olarak alınmaktadır. (2) KSS testinde \% 1 ve \% 5 anlamlılık düzeylerinde kritik değerler sabit terim içeren modeller için, sırasıyla -3.48 ve -2.93 iken, sabit ile birlikte trend içeren modeller için, sırasıyla -3.93 ve -3.40'tır. Söz konusu kritik değerler Sollis testi için, sırasıyla 6.891 ve 4.886 ile 8.799 ve 6.546 'dır. Sollis testi için gözlem sayısı 50 olarak kabul edilmektedir. (3) Sollis testi F istatistiğine dayanmaktadır. (4) Parantez içindeki değerler, GtoS yaklaşımıyla belirlenen, Akaike bilgi kriterini maksimize eden optimal gecikme sayısını göstermektedir. Maksimum gecikme sayısı 6 olarak alınmaktadır.

\section{Varyans Oranı Testleri}

Birim kök testleri, bir serinin ya durağan olduğu ya da durağan olmadığı şeklinde iki uç nokta arasında test yapılmasına imkân tanımaktadır. Hâlbuki seriler hem durağan, hem de durağan olmayan öğeleri bünyesinde bir arada barındırabilmektedir. Bir serinin eşanlı olarak bu iki öğeye sahip olması durumunda, birim kök testleri serinin durağan olmadığına dair boş hipotezi reddedeme eğilimine sahip olmaktadır. Bu nedenle, bir seride durağan olmama özelliğini taşıyan öğenin tespit edilmesi için, varyans oranı testlerine başvurulmaktadır. İlk olarak, Lo ve MacKinlay (1988) tarafından önerildiği gibi sabit varyans ve değişen varyans varsayımları altında $V_{t}$ serisinin tesadüfi yürüyüşs sürecini izleyip izlemediği araştırılmaktadır. Tablo 8'de özetlenen sonuçlardan görüleceği üzere, her iki varsayım altında da $V_{t}$ serisinin tesadüfi süreç izlediğine dair boş hipotez reddedilememektedir. İkinci olarak, Wright (2000) tarafından geliştirilen sıra ( $\mathrm{rank}$ ), sıra puanı (rank score) ve işaret (sign) testleri uygulanmaktadır. Söz konusu bu üç teste göre de, $V_{t}$ serisinin tesadüfi yürüyüşe sahip olduğu boş hipotezi reddedilememektedir. Chow ve Denning (1993) tarafından önerilen bütünleşik test sonuçları da, $V_{t}$ serisinin tesadüfi yürüyüşe sahip olduğuna işaret etmektedir.

Tablo 9

Varyans Oranı Test Sonuçları

\begin{tabular}{cccccccc}
\hline \multicolumn{9}{c}{ Bireysel Testler } & & Bütünleşik Test \\
\hline $\mathrm{k}$ & 5 & 10 & 15 & 20 & 25 & Max $|\mathbf{z}|$ \\
\hline
\end{tabular}




\begin{tabular}{|c|c|c|c|c|c|c|}
\hline \multicolumn{7}{|c|}{ Lo ve MacKinlay Testi } \\
\hline $\operatorname{VR}(k)$ & 1.2004 & 1.4408 & 1.5369 & 1.2674 & 0.9347 & \\
\hline $\mathbf{Z 1}$ & 0.6270 & 0.8949 & & 0.3689 & -0.0799 & 0.8949 \\
\hline & & & 0.8665 & & & \\
\hline Olasılık & 0.4870 & 0.3900 & 0.3920 & 0.7690 & 0.9510 & 0.6140 \\
\hline $\mathbf{Z 2}$ & 0.7875 & 1.0064 & 0.9344 & 0.3981 & -0.0878 & 1.0064 \\
\hline Olasılık & 0.5270 & 0.4040 & 0.4060 & 0.7710 & 0.9610 & 0.6700 \\
\hline \multicolumn{7}{|c|}{ Wright Testi } \\
\hline VR(k) & 1.1279 & 1.1758 & 1.1501 & 0.8896 & 0.4777 & \\
\hline $\mathbf{R 1}$ & 0.4001 & 0.3569 & 0.2422 & -0.1523 & -0.6394 & 0.6394 \\
\hline Olasılık & 0.7780 & 0.8600 & 0.9200 & 0.9690 & 0.8950 & 0.9650 \\
\hline $\operatorname{VR}(k)$ & 1.0936 & 1.1291 & 1.0780 & 0.8046 & 0.4133 & \\
\hline $\mathbf{R 2}$ & 0.2929 & 0.2621 & 0.1259 & -0.2695 & -0.7183 & 0.7183 \\
\hline Olasılık & 0.8030 & 0.8720 & 0.9590 & 0.9600 & 0.8610 & 0.9190 \\
\hline $\operatorname{VR}(k)$ & 1.0340 & 1.3447 & 1.3858 & 1.0723 & 0.6800 & \\
\hline $\mathbf{S}$ & 0.1065 & 0.6999 & 0.6227 & 0.0998 & -0.3918 & 0.6998 \\
\hline Olasılık & 0.8970 & 0.6250 & 0.7620 & 0.9770 & 0.9650 & 0.9370 \\
\hline
\end{tabular}

Notlar: (1) VR(k), k gecikmesindeki varyans oranını göstermektedir. (2) Z1 ve Z2, sırasıyla, Lo ve MacKinlay (1988) tarafından önerilen yaklaşımla sabit varyans ve değişen varyans varsayımı altında hesaplanan $Z$ istatistiklerini göstermektedir. R1, R2 ve S ise, Wright (2000) tarafindan, sırasıyla, sıra, sıra puanı ve işaret testlerine dayalı olarak hesaplanan $\mathrm{Z}$ istatistiklerini göstermektedir. Her beş testte de, varyans oranları dağılımı Kim (2006) tarafından önerilen aşırı koruyan halka (wild bootstrap) tekniğiyle elde edilmektedir. (3) Max $|z|$ istatistiği Chow ve Denning (1993) test istatistiğini göstermektedir.

\section{Kesirli Bütünleşme Modelleri}

Birim kök testleri, bir serinin bütünleşme derecesinin (d) tam sayı olmasını zorunlu kılmaktadır. Gerçekte, ekonomik ve finansal zaman serilerinin çoğu ne sıfırıncı dereceden bütünleşik, I(0), ne de birinci dereceden bütünleşik, I(1), sürecine uygunluk göstermektedir. ARFIMA modelleri ise, birim kök testlerinin aksine, bütünleşme derecesinin reel değerler alabilmesine izin vermektedir. Söz konusu modellerde $V_{t}$ serisinin durağan olduğu boş hipotezi $\left(H_{0}: d=0\right)$ doğrudan test edilebildiği gibi, birim kök testlerine benzer şekilde durağan olmadığ $d^{*}=d-1$ iken $d^{*}$ parametresi Geweke ve Porter-Hudak (1983), Robinson (1995) ile Phillips (1999) tarafından geliştirilen yarı parametrik yaklaşımla tahmin edilmektedir.

Tablo 10

ARFIMA Test Sonuçları

\begin{tabular}{cccccccccc}
\hline & \multicolumn{3}{c}{ Geweke ve Porter-Hudak } & \multicolumn{3}{c}{ Robinson } & \multicolumn{3}{c}{ Phillips } \\
\cline { 2 - 10 } & $\mathbf{d}^{*}$ & t ist. & Olasılık & d* $^{*}$ & t ist. & Olasılık & d* & t ist. & Olasılık \\
\hline 0.45 & 0.402 & 0.363 & 0.741 & 0.394 & 0.359 & 0.732 & 0.370 & 0.427 & 0.687 \\
0.50 & 0.169 & 0.199 & 0.852 & 0.564 & 0.759 & 0.470 & 0.205 & 0.311 & 0.767
\end{tabular}




$\begin{array}{llllllllll}0.55 & 0.357 & 0.547 & 0.604 & 0.392 & 0.721 & 0.487 & 0.322 & 0.633 & 0.544 \\ 0.60 & 0.136 & 0.251 & 0.808 & 0.111 & 0.241 & 0.814 & 0.191 & 0.421 & 0.683 \\ 0.65 & 0.093 & 0.216 & 0.834 & 0.090 & 0.242 & 0.813 & 0.170 & 0.470 & 0.647 \\ 0.70 & 0.037 & 0.103 & 0.920 & 0.043 & 0.138 & 0.892 & 0.127 & 0.412 & 0.686\end{array}$

Notlar: (1) m optimal ordinat sayısını göstermektedir. (2) $d^{*}=d-1$.

Tablo 10'da yer alan sonuçlar incelendiğinde, her üç teste göre de tahmin edilen $d^{*}$ parametrelerinin $\% 5$ düzeyinde istatistiki olarak anlamlı olmadığı ve dolayısıyla $V_{t}$ serisinin durağan olmadığına dair boş hipotezin reddedilemediği görülmektedir.

\section{Paranın Dolaşım Hızını Etkileyen Faktörlerin Belirlenmesi}

Paranın dolaşım hızı ve açılayıcı değişkenler arasındaki ilişki (19) numaralı denklem çerçevesinde 1970-2017 yıllarını kapsayan zaman serileriyle birlikte NARDL sınır testi kullanılarak ortaya konmaktadır. Öncelikle düzmece regresyon sorunundan kaçınmak için, açılayıcı değişkenlerin durağanlığı Dickey ve Fuller (1981) tarafindan formüle edilen Genişletilmiş Dickey-Fuller (Augmented Dickey-Fuller, ADF), Ng ve Perron (2001) tarafindan formüle edilen Ng-Perron (NP), Kwiatkowski vd. (1992) tarafından geliştirilen Kwiatkowski-PhillipsSchmidt-Shin (KPSS) geleneksel birim kök testleri ve Perron (1997) tarafından geliştirilen yapısal kırılma içeren birim kök testi yöntemler ile sınanmakta, optimal gecikme uzunlukları Schwarz bilgi kriteri (BIC) yardımıyla belirlenmektedir. Değişkenlerin düzey değerlerinde durağan olmadığı belirlenmekte, birinci farkları alındı ̆̆ında ise ADF, Ng-Perron $(N P)$ ve Perron testleri değişkenlerin durağan olmadığını reddetmekte, Kwiatkowski-Phillips-SchmidtShin (KPSS) testi de değişkenlerin durağan olduğunu kabul etmektedir. NARDL yönteminin kullanılabilmesi için gerekli koşullar arasında yer alan serilerin sıfırıncı ve birinci dereceden bütünleşik olması Schwarz bilgi kriteri yardımıyla belirlenen optimal gecikme uzunlukları ile verilerin durağanlık sınamalarında sağlanmaktadır.

Tablo 11

Birim Kök Testi Sonuçları

\begin{tabular}{|c|c|c|c|c|c|c|c|}
\hline \multicolumn{2}{|c|}{ Değişkenler } & \multicolumn{2}{|c|}{$Y_{t}$} & \multicolumn{2}{|c|}{$i_{t}$} & \multicolumn{2}{|c|}{$\varphi_{t}$} \\
\hline Testler & & Sabit & $\begin{array}{c}\text { Sabit ve } \\
\text { Trend }\end{array}$ & Sabit & $\begin{array}{l}\text { Sabit ve } \\
\text { Trend }\end{array}$ & Sabit & $\begin{array}{l}\text { Sabit ve } \\
\text { Trend }\end{array}$ \\
\hline ADF & & $-6.552(1)^{*}$ & $-6.507(1)^{*}$ & $-7.029(1)^{*}$ & $-7.507(1)^{*}$ & $-5.965(1)^{*}$ & $-5.895(1)^{*}$ \\
\hline KPSS & & $0.070(1)^{*}$ & $0.051(1)^{*}$ & $0.425(1)^{*}$ & $0.071(1)^{*}$ & $0.100(1)^{*}$ & 0.104 (1) \\
\hline \multirow{2}{*}{ NP } & $\mathbf{M Z}_{\mathbf{a}}$ & $-22.51(1)^{*}$ & $-22.81(1)^{* *}$ & $-22.92(1)^{*}$ & $-22.11(1)^{* *}$ & $-18.91(1)^{*}$ & $-21.56(1)^{* *}$ \\
\hline & $\mathbf{M Z}_{\mathrm{t}}$ & $-3.345(1)^{*}$ & $-3.367(1)^{* *}$ & $-3.384(1)^{*}$ & $-3.319(1)^{* *}$ & $-3.071(1)^{*}$ & $-3.259(1)^{* *}$ \\
\hline \multirow{2}{*}{ Perron } & AO & $-7.507(1)^{*}$ & $-7.246(1)^{*}$ & $-7.970(1)^{*}$ & $-8.796(1)^{*}$ & $-6.357(1)^{*}$ & $-7.469(1)^{*}$ \\
\hline & IO & $-7.382(1)^{*}$ & $-7.161(1)^{*}$ & $-7.788(1)^{*}$ & $-8.364(1)^{*}$ & $-6.252(1)^{*}$ & $-7.260(1)^{*}$ \\
\hline
\end{tabular}


Notlar: (1) Kritik değerler ADF testi için Fuller (1976), NP testleri için Ng ve Perron (2001), KPSS testi için Kwiatkowski vd. (1992) ve Perron testi için ise Perron (1997) tarafından hazırlanan tablo değerlerine ve gözlem sayısına uygun olarak alınmaktadır. (2) ADF testinde testlerinde $\% 1$ ve $\% 5$ anlamlılık düzeylerinde kritik değerler sabit terim içeren modeller için, sırasıyla -3.577 ve -2.925 iken, sabit ile birlikte trend içeren modeller için -4.165 ve -3.508 'tir. Söz konusu kritik değerler, sırasıyla, KPSS testi için 0.739 ve 0.463 ile 0.216 ve $0.146 ; \mathrm{NP} / \mathrm{MZ}_{\mathrm{a}}$ için -13.80 ve -8.10 ile -23.80 ve $-17.30 ; \mathrm{NP} / \mathrm{MZ}_{\mathrm{t}}$ için -2.58 ve -1.98 ile -3.42 ve -2.91 'dir. Perron testinde ise kritik değerler uyarlamanın anlık ve kademeli olduğu modelde sabit terimdeki ve sabit terim ve trenddeki kırılmalar için, sırasılyla -4.95 ve -4.44 ile $-5,72$ ve $-5,18$ 'dir. (3) Parantez içi değerler serilerin durağanlık seviyelerini göstermektedir. (4) Maksimum gecikme sayıs 6 olarak alınmaktadır. (5) * ve ** işaretleri \% 1 ve \% 5 anlamlılık düzeyinde boş hipotezin ADF, NP ve Perron testleri için reddedildiğini, KPSS testi için ise kabul edildiğini göstermektedir.

NARDL yönteminde, modeldeki değişkenler kendi gecikmeli ve diğer tüm değişkenlerin cari ve gecikmeleri değerlerine bağlı olarak ifade edilmekte, bu nedenle optimal gecikme uzunluğunun belirlenmesi önem kazanmaktadır. Literatürde yer alan çalışmalarda maksimum gecikme uzunluğunun önsel olarak veya bilgi kriterleri çerçevesinde belirlenebilse de, bu çalışmada Lütkepohl (1993) tarafından yapılan çalışma baz alınarak maksimum gecikme uzunluğu iki olarak belirlenmekte, NARDL modeli çerçevesinde tahmin edilen modelde yer alan değişkenler için maksimum gecikme düzeyinden başlanarak istatistiksel olarak anlamlı olmayan değişkenler modelden çıkartılarak Tablo 12'de gösterilen NARDL modeli tahminine, değişkenlerin uzun dönem katsayılarına ve asimetrik etkilerine ve diagnostik testlere ulaşılmaktadır16. Mevduat faiz oranlarının kısa dönem asimetrisinin, reel efektif döviz kurunun da uzun ve kısa dönem asimetrisinin istatistiksel olarak anlamlı bulunduğu, uzun dönemde mevduat faiz oranlarındaki ve reel efektif döviz kurlarındaki pozitif değişimlerin negatif değişimlere göre paranın dolaşım hızı üzerinde daha etkili olduğu sonucuna ulaşılmaktadır.

Tablo 12

NARDL Tahmin Sonuçlart

Panel A: Bă̆ımlı Değişken $\Delta \mathrm{V}$

\begin{tabular}{lccccc}
\hline Değişkenler & Katsayı & t-istatistiği & Olasılık Değeri & Panel B: Uzun Dönem Katsayıları \\
\hline & 72.6268 & 3.6879 & 0.0012 & $L_{y}$ & 2.479 \\
& 0.25530 & 4.6797 & 0.0001 & $L_{i-}$ & -0.262 \\
$\Delta V_{-1}$ & 0.1791 & 1.4535 & 0.1591 & $L_{i+}$ & -0.432 \\
$\Delta Y$ & 0.6511 & 0.8777 & 0.3888 & $L_{\varphi-}$ & -1.860 \\
$\Delta Y_{-1}^{* *}$ & 1.5633 & 2.4899 & 0.0201 & $L_{\varphi+}$ & 1.900 \\
$\Delta Y_{-2}^{* *}$ & 1.4544 & 2.7289 & 0.0117 & & Panel C: Asimetrik Etkiler \\
$i^{-}$ & 0.2861 & 1.4868 & 0.1501 &
\end{tabular}

16 Lütkepohl (1993) tahmin edilen modeldeki endojen değişken sayısına ve örneklem büyüklüğüne göre optimal gecikme uzunluğunu $M l_{a g}=T^{l / 3} / M$ formülüne dayanarak belirlemekte, $T=48$ ve $M=3$ olarak alındığında optimal gecikme uzunluğu 1-2 olmaktadır. 


\begin{tabular}{lccccc}
$\Delta i^{+}$ & -0.0083 & -0.0660 & 0.9479 & $\mathrm{~W}_{\mathrm{LR}, \mathrm{i}}$ & 1.185 \\
$\Delta i_{-1}{ }^{+* *}$ & -0.2959 & -2.2680 & 0.0326 & $\mathrm{~W}_{\mathrm{SR}, \mathrm{i}}$ & $6.711^{* *}$ \\
$\Delta i_{-2}{ }^{+* *}$ & -0.2411 & -2.0840 & 0.0480 & $\mathrm{~W}_{\mathrm{LR}, \varphi}$ & $129.647^{*}$ \\
$\Delta \varphi^{-}$ & -0.1247 & -0.3991 & 0.6934 & $\mathrm{~W}_{\mathrm{SR}, \varphi}$ & $6.005^{* *}$ \\
$\Delta \varphi^{-}{ }^{*}$ & -1.5730 & -3.8227 & 0.0008 & \\
$\Delta \varphi^{+}$ & -0.3994 & -1.5764 & 0.1280 & Panel D: Diagnostik Testler \\
$\Delta \varphi^{+}{ }_{-1}^{* * *}$ & 0.5746 & 2.0175 & 0.0550 & $R^{2}=0.6429$ \\
$V_{-1}{ }^{*}$ & -1.0993 & -7.4398 & 0.0000 & $\mathrm{~F}_{\mathrm{PSS}}=10.400$ \\
$Y_{-1}{ }^{*}$ & -2.7254 & -3.6273 & 0.0013 & $\chi^{2} \mathrm{BG}(\mathrm{AR}(1))=1.156(0.282)$ \\
$i_{-1}^{*}$ & 0.2882 & 2.9740 & 0.0066 & $\chi^{2} \mathrm{BP}=15.021(0.721)$ \\
$i^{+}{ }_{-1}^{*}$ & 0.4747 & 4.0462 & 0.0005 & $\mathrm{~F}_{\mathrm{RR}}=2.064(0.109)$ \\
$\varphi^{-}{ }_{-1}^{*}$ & 2.0448 & 6.3368 & 0.0000 & $\chi^{2} \mathrm{JB}=2.078(0.354)$ \\
$\varphi^{+}{ }_{-1}^{*}$ & -2.0888 & -6.3049 & 0.0000 & \\
\hline
\end{tabular}

Notlar: (1) En uygun NARDL modelinin elde edilmesinde maksimum gecikme uzunluğu 2 alınmakta ve Shin, Yu vd. (2014)'in çalışmasına uygun olarak GtoS yaklaşımı benimsenmektedir. (2) Narayan (2005) tarafından hazılanan tabloda kısıtlanmamış sabit ve trend içeren modelde $k=5$ ve $n=50$ için belirlenen eşbütünleşme kritik değerleri 4.672 ve 6.232 'dir. (3) $\Delta$ birinci dereceden fark alma operatörünü ifade etmektedir. (4) *,** ve *** işaretleri boş hipotezin s1rasıyla $\% 1, \% 5$ ve $\% 10$ anlamlılık düzeyinde reddedildiğini göstermektedir. (5) $L, W_{L R}$ ve $\mathrm{W}_{\mathrm{SR}}$ notasyonları sirasıyla değişkenlerin uzun dönem katsayısını, uzun ve kısa dönemde asimetrik etkilerini göstermektedir. Asimetrik etkiler, uzun dönemde değişkenlerin negatif ve pozitif uzun dönem katsayılarının, kısa dönemde ise değişkenlerin negatif ve pozitif değişimlerinin toplamının eşitliğinin sınanması ile belirlenmektedir. (6) PSS, BG, BP, JB ve RR sırasıyla Pesaran, Shin ve Smith sınır testinin, Breusch-Godfrey otokorelasyon testinin, Breusch-Pagan değişken varyans testinin, Jarque-Bera normallik testinin, RR Ramsey-Reset model spesifikasyon testinin kısaltması olarak kullanılmaktadır. (7) Panel D'de görüldüğü üzere, model kurma hatası, değişken varyans ve otokorelasyon problemi bulunmamaktadır.

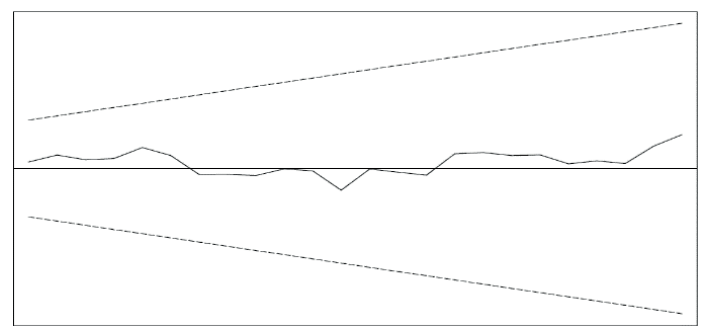

(a) CUSUM Test

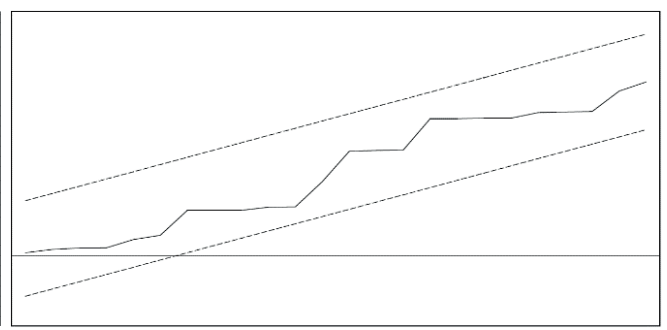

(b) CUSUMQ Test

Grafik 2. Zaman içerisinde tahmin edilen modelin yapısal kırılmaları

Notlar: (1) CUSUM ve CUSUMQ testi sırasıyla ardışık hataların ve hata karelerinin kümülatif toplamınını ifade etmektedir. (2) Grafik 2’de görüldüğü üzere tahmin edilen modelde yapısal değişiklik olmadığı görülmektedir. 


\section{Değerlendirme ve Sonuç}

\section{Değerlendirme ve Öneriler}

Bu çalışma kapsamında paranın dolaşım hızı içsel bağıntı fonksiyonu, geleneksel, yapısal kırılma içeren ve doğrusal olmayan birim kök testleri, varyans oranı testleri ve kesirli bütünleşme modelleri (ARFIMA); McKinnon (1996) modeli baz alınarak oluşturulan para talebi fonksiyonu ise doğrusal olmayan gecikmesi dağıtılmış otoregresif model (NARDL) yardımıla incelenmektedir.

Paranın dolaşım hızı ile ilgili olarak, Ljung-Box testi içsel bağıntı olduğu boş hipotezini reddedememekte, ADF, GF-GLS, PP ve NP geleneksel birim kök testleri serinin birim kök içerdiği ve durağan olmadığı boş hipotezini reddedememekte, KPSS testi ise serinin durağan olduğu boş hipotezini kabul edilememektedir. Yapısal kırılma içeren birim kök testleri arasında yer alan PV ve CMR testleri sabitte kırılma altında hem anlık hem de kademeli uyarlama durumunda, Perron testi sabitte kırılma altında kademeli uyarlama durumunda, ZA ve LP testleri sabitte ve sabitte ve trendde kırılma durumlarında, LS1 ve LS2 testleri ise sabit ve trendde kırılma durumlarında serinin durağan olmadığı boş hipotezini reddetmekte; Perron testi trendde ve sabit ve trendde kırılma altında hem anlık hem de kademeli uyarlama durumunda, ZA ve LP testleri trendde kirılma durumunda ve LS1 ve LS2 testleri ise sabitte kırılma durumunda boş hipotezi reddedememektedir. KSS ve Sollis doğrusal olmayan birim kök testleri ise serinin birim kök içerdiği boş hipotezini reddedememektedir. Lo ve McKinlay Wright ve Chow ve Dening varyans oranı testleri serinin tesadüfi yürüyüş süreci izlediğine dair boş hipotezi reddememektedir. Ayrıca, Geweke ve Porter-Hudak, Robinson ve Phillips kesirli bütünleşme modelleri serinin durağan olmadığına dair boş hipotezi reddedemedikleri görülmektedir. Paranın dolaşım hızının tesadüfi yürüyüşsüreci izlediği ve geleneksel ve doğrusal olmayan birim kök testleri, kesirli bütünleşme modellerinin aksine yapısal kırılmalar dikkate alındığında durağan olabileceği değerlendirilmektedir.

Para talebi fonksiyonu ile ilgili olarak, bağımlı değişken olan paranın dolaşım hızı ile açıklayıcı değişkenler olarak belirlenen reel gayri safi yurt içi hasıla, reel efektif döviz kuru ve tasarruf mevduatları ile Türk Lirası cinsinden mevduat faiz oranı serileri birinci dereceden fark durağan süreci izlediği için bu seriler aralarındaki eşbütünleşik ilişki asimetrik etkileri de kapsayacak şekilde NARDL sınır testi ile analiz edilmektedir. Tahmin edilen modeldeki değişkenler arasında uzun dönemli ilişki bulunduğu, tahmin edilen modelin Cusum ve $\mathrm{Cu}-$ sumQ testi çerçevesinde kararlı olduğu, diagnostik testlerin hepsinin modelin varsayımlarını karşıladığı görülmektedir. Ayrıca, para talebinin gelir, faiz oranı ve döviz kuru esnekliklerinin sırasıyla pozitif, negatif ve pozitif olduğu belirlenmektedir. Gelir arttıkça paranın lüks mal gibi davranması nedeniyle para talebinin gelir esnekliğinin pozitif olması, faiz oranlarının para talebinin firsat maliyetini yansıtması nedeniyle para talebinin faiz esnekliğinin negatif 
olması, Arize, Malindretos ve Shwiff (1999) tarafından belirtildiği üzere milli paranın değer kaybettikçe ekonomik ajanların ellerinde tuttukları yabancı varlıkların değerlenmesi kanalıyla servetin ve para talebinin artması nedeniyle para talebinin döviz kuru esnekliğinin pozitif olması hem beklentilerle hem de Özcan ve Arı (2013) ve Gencer ve Arısoy (2013) gibi literatürde yer alan çalışmalarla uyumlu olduğu belirlenmektedir.

Para talebinin faiz oranı esnekliğinin mutlak değer olarak birden küçük olması faiz oranındaki değişimlerin para talebini etkileyebileceğini, döviz kuru esnekliğinin ise birden büyük olması para talebinin döviz kuru değişimlerine aşırı duyarlı olduğunu göstermektedir. Bu nedenle, TCMB'nin uyguladığı enflasyon hedeflemesinin başarılı olmasının ön koşulu olan istikrarlı bir para talebi fonksiyonu için makroekonomik ve finansal istikrar politikalarının faiz oranını ve reel efektif döviz kurunu kontrol edebilecek şekilde uygulanması gerekmektedir. Ayrıca, paranın gelir dolaşım hızının istikrarlı olmamasına rağmen para talebi fonksiyonun istikrarlı olması nedeniyle incelenen dönemde TCMB başarılı olarak değerlendirilmekte, $M_{2}$ parasal büyüklüğünün reel değişkenler üzerinde etkili olduğu görülmektedir.

\section{Sonuç}

Para talebinin ve paranın dolaşım hızının istikrarı parasal iktisatın üzerinde en fazla çalışma yapılan konularından biri olmasına rağmen, kullanılan tekniklerin ve değişkenlerin farklılaşması nedeniyle bu kavramların istikrarı üzerinde tam olarak uzlaşılamamaktadır. $\mathrm{Bu}$ nedenle, ekonometri alanında geliştirilen her yeni teknik ile paranın dolaşım hızının istikrarı lehine sonuçlar elde edilmeye çalışılmakta, özellikle uzun dönemler içeren veri setlerinin kullanıldığı çalışmalarda genel olarak paranın dolaşım hızının ve para talebinin istikrarı aleyhine sonuçlar elde edildiği görülmektedir. Bu sonuçlar 1şığında, bu çalışmada, 1970 yılından başlayarak yaklaşı olarak yarım yüzyılı kapsayan veri setiyle, paranın dolaşım hızının Türkiye'de istikrarı ve para talebinin belirleyicileri araştırılmaktadır.

Geleneksel ve doğrusal olmayan birim kök testleri, varyans oranı testleri ve kesirli bütünleşme modelleri paranın dolaşım hızının durağan olmadığını gösterse de, özellikle Merkez Bankası'nın bağımsız kılındığı, yapısal dönüşümlerin ve bankacılık reformlarının gerçekleştirildiği ve enflasyon hedeflemesine geçildiği 2000'li yıllarda gözlenen yapısal kırılmalar dikkate alındığında, birçok yapısal kırılma içeren birim kök testi paranın dolaşım hızının durağan olabileceğini göstermektedir. Paranın talebinin gelir esnekliğinin pozitif, faiz esnekliğinin negatif ve döviz kuru esnekliğinin pozitif olması beklentilerle ve literatürdeki çalışmalarla uyumlu bulunmakta, kısa dönemde faiz oranındaki ve kısa ve uzun dönemde reel efektif döviz kurundaki pozitif değişimlerinin negatif değişimlere göre para talebi üzerinde daha etkili olduğu belirlenmektedir. Ayrıca, döviz kuru esnekliğinin pozitif işaretli olması servet etkisinin varlığını destekleyici bir sonucu yansıtmaktadır. 
Finansal Destek: Yazarlar bu çalışma için finansal destek almamışlardır.

\section{Kaynakça/References}

Ahad, M. (2017). Financial development and money demand function: cointegration, causality and variance decomposition analysis for Pakistan. Global Business Review, 18(4), 811-824.

Algan, N. ve Gencer, S. (2011). Türkiye'de para talebi fonksiyonun modellenmesi. Çukurova Üniversitesi Sosyal Bilimler Enstitüsü Dergisi, 20(1), 195-212.

Alsamara, M., \& Mrabet, Z. (2019). Asymmetric impacts of foreign exchange rate on the demand for money in turkey: New evidence from nonlinear ARDL. International Economics and Economic Policy, 16(2), 335-356.

Apergis, N., \& Cooray, A. (2015). Asymmetric interest rate pass-through in the us, the uk and australia: new evidence from selected individual banks. Journal of Macroeconomics, 45, 155-172.

Arize, A. C., Malindretos, J., \& Shwiff, S. S. (1999). Structural breaks, cointegration, and speed of adjustment evidence from 12 LDCs money demand. International Review of Economics \& Finance, 8(4), 399-420.

Atgür, M. ve Altay, N. O. (2015). Enflasyon hedeflemesi sürecinde para talebi istikrarının ardl modeli yaklaşımı ile analizi: Türkiye ve Endonezya örneği. Eskişehir Osmangazi Üniversitesi İIBF Dergisi, 10(1), 79-97.

Bahmani-Oskooee, M., \& Gelan, A. (2009). How stable is the demand for money in African countries. Journal of Economic Studies, 36(3), 216-235.

Bahmani-Oskooee, M., \& Gelan, A. (2019). Asymmetric effects of exchange rate changes on the demand for money in Africa. Applied Economics, 51(31), 3365-3375.

Bahmani-Oskooee, M., Halicioglu, F., \& Bahmani, S. (2017). Do exchange rate changes have symmetric or asymmetric effects on the demand for money in Turkey? Applied Economics, 49(42), 4261-4270.

Bahmani-Oskooee, M., \& Karacal, M. (2006). The demand for money in Turkey and currency substitution. Applied Economics Letters, 13(10), 635-642.

Ball, L. (2012). Short-run money demand. Journal of Monetary Economics, 59(7), 622-633.

Ball, R. J. (2017). Inflation and the Theory of Money. London: Routledge.

Basher, S., Fachin, S. (2012). Investigating Long-Run Demand for Broad Money in the Gulf Arab Countries, DSS Empirical Economics and Econometrics, Working Papers Series, DSS-E3 WP 2012/6, La Spienza University.

Baunto, A. L. Bordes, C. Maveyraud, S., \& Rous P. (2011). Money Growth and Velocity with Structural Breaks: Evidence from the Philippines. Université Paris1 Panthéon-Sorbonne, 18, 71-81.

Beckmann, J., Belke, A., \& Kühl, M. (2011). The Dollar-Euro exchange rate and macroeconomic fundamentals: a time-varying coefficient approach. Review of World Economics, 147(1), 11-40.

Belke, A. H., \& Czudaj, R. (2010). Is Euro area money demand stable? cointegrated var versus single equation techniques. Ruhr Economic Paper, 171, 1-45.

Belongia, M. T., \& Ireland, P. N. (2015). Interest rates and money in the measurement of monetary policy. Journal of Business \& Economic Statistics, 33(2), 255-269.

Bussiere, M. (2013). Exchange rate pass-through to trade prices: The role of nonlinearities and asymmetries. Oxford Bulletin of Economics and Statistics, 75(5), 731-758. 
Cho, H. C., \& Ramirez, M. D. (2016). Money demand in Korea: A cointegration analysis, 1973-2014. Business and Economic Research, 6(1), 96.

Chow, K.V., \& Denning, K.C. (1993). A simple multiple variance Ratio Test. Journal of Econometrics, 58(3): 385-401.

Chuliá, H., Martens, M., \& Van Dijk, D. (2010). Asymmetric effects of federal funds target rate changes on S\&P100 stock returns, volatilities and correlations. Journal of Banking \& Finance, 34(4), 834-839.

Clemente, J., Montanes, A., \& Reyes, M. (1998). Testing for a unit root in variables with a double change in the mean. Economics Letters, 59(2), 175-182.

Dagher, J. C., \& Kovanen, A. (2011). On the stability of money demand in ghana: a bounds testing approach. IMF Working Papers, 1-18.

Darıcı, B., Taşçı, H. M. ve Erbaykal, E. (2009). Ters para ikamesi süreci ve döviz kuru oynaklığı Türkiye örneği. Dogus University Journal, 10(1), 102-117.

Delatte, A. L., \& López-Villavicencio, A. (2012). Asymmetric exchange rate pass-through: Evidence from major countries. Journal of Macroeconomics, 34(3), 833-844.

Dickey, D. A., \& Fuller, W. A. (1981). Likelihood Ratio statistics for autoregressive time series with a unit root. Econometrica: Journal of the Econometric Society, 49(4), 1057-1072.

Dreger, C., \& Wolters, J. (2015). Unconventional monetary policy and money demand. Journal of Macroeconomics, 46, 40-54.

Dülger, F. (2002). Income velocity of money (M2): The case of Turkey, 1986-2000. Cash Conversion Cycle, Cash Management and Profitability: An Empirical Study on the ISE Traded Companies, 6(22), 33.

Elliott, G., Rothenberg, T., \& Stock, J. H. (1996). Efficient tests for an autoregressive unit root. Econometrica, 64(4), 813-836.

Fisher, I. (1911). “ The Equation of exchange,” 1896-1910. The American Economic Review, 1(2), 296-305.

Foresti, P., \& Napolitano, O. (2013). Modelling long-run money demand: A panel data analysis on nine developed economies. Applied Financial Economics, 23(22), 1707-1719.

Frenkel, J. A. (2010). Exchange rates and international macroeconomics. Chicago: University of Chicago Press.

Friedman, M. (1959). The demand for money: Some theoretical and empirical results. Journal of Political Economy, 67(4), 327-351.

Friedman, M., \& Schwartz, A. J. (1963). A monetary history of the US 1867-1960. Princeton: Princeton University Press.

Fuller, W. A. (1976). Introduction to statistical time series. Wiley: New York.

Gencer, S., Arisoy, I. (2013). Türkiye'de uzun dönem geniş (M2Y) Para talebinin tahmini: zamana göre değişen katsayılar yönteminden bulgular. Ege Akademik Bakış Dergisi, 13(4), 515-526.

Geweke J., Porter-Hudak, S. (1983). The estimation and application of long memory time series models. Journal of Time Series Analysis, 4(4), 221-238.

Gould, J. P., \& Nelson, C. R. (1974). The stochastic structure of the velocity of money. The American Economic Review, 64(3), 405-418.

Granger, C. W., Joyeux, R. (1980). An introduction to long-memory time series models and fractional differencing. Journal of Time Series Analysis, 1(1), 15-29. 
Hamzah, N. H., Masih, M. (2018). Revisiting Effectiveness of Interest Rate as a Tool to Control Inflation: Evidence from Malaysia Based on ARDL and NARDL.

Hannan, E. J., \& Quinn, B. G. (1979). The determination of the order of an autoregression. Journal of the Royal Statistical Society. Series B (Methodological), 41(2), 190-195.

Hien, B. Q., \& Long, P. D. (2019). Stability of Vietnam money demand function: an empirical application of multiple testing with a structural break. In International Conference of the Thailand Econometrics Society (pp. 670-683). Springer, Cham.

Hossain, A. A. (2012). Modelling of narrow money demand in Australia: An ARDL cointegration approach, 1970-2009. Empirical Economics, 42(3), 767-790.

Humphrey, T. M. (1993). Money, Banking and Inflation. Books.

Hye, Q. M. A. (2009). Financial innovation and demand for money in Pakistan. The Asian Economic Review, 51(2), 219-228.

Ireland, P. N. (2010). Monetary transmission mechanism. In Monetary Economics (pp. 216-223). Palgrave Macmillan, London.

Iyoboyi, M., \& Pedro, L. M. (2013). The demand for money in Nigeria: Evidence from bounds testing approach. Business and Economics Journal.

Jammazi, R., Lahiani, A., \& Nguyen, D. K. (2015). A wavelet-based nonlinear ARDL model for assessing the exchange rate pass-through to crude oil prices. Journal of International Financial Markets, Institutions and Money, 34, 173-187.

Jonung, L. (2018). Demand for money: An analysis of the long-run behavior of the velocity of circulation. London: Routledge.

Kapetanios, G., Shin, Y., \& Snell, A. (2003). Testing for a unit root in the nonlinear STAR framework. Journal of Econometrics, 112(2), 335-346.

Karaman, K. K., Pamuk, Ş. ve Yıldırım-Karaman, S. (2019). Money and monetary stability in Europe, 13001914. Journal of Monetary Economics, 75, 69-92

Keynes, J. M. (1936). The General Theory of Money, Interest and Employment. Reprinted in the Collected Writings of John Maynard Keynes, 7.

Kim, J. H. (2006). Wild bootstrapping variance Ratio tests. Economics Letters, 92(1), 38-43.

Korhonen, I., \& Mehrotra, A. (2010). Money demand in post-crisis Russia: Dedollarization and remonetization. Emerging Markets Finance and Trade, 46(2), 5-19.

Kumar, S. (2011). Financial reforms and money demand: Evidence from 20 developing countries. Economic Systems, 35(3), 323-334.

Kumar, S., \& Rao, B. B. (2012). Error-correction based panel estimates of the demand for money of selected asian countries with the extreme bounds analysis. Economic Modelling, 29(4), 1181-1188.

Kumar, S., \& Webber, D. J. (2013). Australasian money demand stability: Application of structural break tests. Applied Economics, 45(8), 1011-1025.

Kumar, S., Webber, D. J., \& Fargher, S. (2013). Money demand stability: A case study of Nigeria. Journal of Policy Modeling, 35(6), 978-991.

Kwiatkowski, D., Phillips, P.C.B., Schmidt, P., \& Shin, Y. (1992). Testing the null hypothesis of stationarity against the alternative of a unit root. Journal of Econometrics, 54(1), 159-178. 
Latheef, U. A., \& Masih, M. (2017). Asymmetrical Effects of Macro Variables on Commercial Bank Deposits: Evidence from Maldives Based on NARDL.

Lee, J., \& Strazicich, M. C. (2003). Minimum lagrange multiplier unit root test with two structural breaks. Review of Economics and Statistics, 85(4), 1082-1089.

Lee, J., \& Strazicich, M. C. (2004). Minimum LM unit root test with one structural break. Appalachian State University Department of Economics Working Paper, No: 04-17.

Ljung, G. M., \& Box, G. E. (1978). On a measure of lack of fit in time series models. Biometrika, 65(2), 297-303.

Lo, A.W., \& MacKinlay, A. C. (1988). Stock market prices do not follow random walks: Evidence from a simple specification test. Review of Financial Studies, 1(1), 41-66.

Lumsdaine, R. L., \& Papell, D. H. (1997). Multiple trend breaks and the unit root hypothesis. Review of Economics and Statistics, 79(2), 212-218.

Lütkepohl, H. (1993). Introduction to multivariate Time Series Analysis. Berlin: Springer-Verlag.

Mansaray, M., \& Swaray, S. (2012). Financial liberalization, monetary policy and money demand in Sierra Leone. Journal of Monetary and Economic Integration, 12(2), 62-90.

McKinnon, R. I. (1996). The rules of the game: International money and exchange rates. London: MIT Press.

McKinnon, R. I. (2010). Money and capital in economic development. Washington: Brookings Institution Press.

Mogliani, M., \& Urga, G. (2018). On the Instability of long-run money demand and the welfare cost of inflation in the United States. Journal of Money, Credit and Banking, 50(7), 1645-1660.

Mohammad, S. D., Wasti, S. K., Lal, I., \& Hussain, A. (2009). An empirical investigation between money supply, government expenditure, output \& prices: The Pakistan evidence. European Journal of Economics, Finance and Administrative Sciences, 17(9), 60-68.

Narayan, P. K. (2005). The saving and investment nexus for China: Evidence from cointegration tests. Applied economics, 37(17), 1979-1990.

Narayan, P. K., Narayan, S., \& Mishra, V. (2009). Estimating money demand functions for South Asian Countries. Empirical Economics, 36(3), 685-696.

Nchor, D., \& Adamec, V. (2016). Investigating the stability of money demand in Ghana. Procedia-Social and Behavioral Sciences, 220, 288-293.

$\mathrm{Ng}, \mathrm{S}$., Perron, P. (2001). Lag length selection and the construction of unit root tests with good size and power. Econometrica, 69(6), 1519-1554.

Odhiambo, N. M. (2009). Energy consumption and economic growth nexus in Tanzania: An ARDL bounds testing approach. Energy Policy, 37(2), 617-622.

Ogunmuyiwa, M. S., \& Ekone, A. F. (2010). Money supply-economic growth nexus in Nigeria. Journal of Social Sciences, 22(3), 199-204.

Oliver, A., Jareño Cebrián, F., Tolentino García-Abadillo, M., \& González Pérez, M. D. L. O. (2019). Impact of changes in the level, slope and curvature of interest rates on US sector returns: an asymmetric nonlinear cointegration approach. Economic Research, 32(1), 1275-129. Doi: 10.1080/1331677X.2019.1632726

Omer, M. (2010). Velocity of money functions in pakistan and lessons for monetary policy. SBP Research Bulletin, 6(2), 37-55. 
Özcan, B., Ayşe, A. R. I. (2013). Para talebinin belirleyenleri ve istikrarı üzerine bir uygulama: Türkiye örneği. Yönetim ve Ekonomi: Celal Bayar Üniversitesi İktisadi ve İdari Bilimler Fakültesi Dergisi, 20(2), 105-120.

Özçalık, M. (2014). Türkiye'de para talebi fonksiyonu: Bir ARDL yaklaşımı. Sosyal Ekonomik Araştırmalar Dergisi, 14(27), 359-373.

Perron, P. (1989). The great crash, the oil price shock and the unit root hypothesis. Econometrica, 57(6), 1361-1401.

Perron, P. (1997). Further evidence from breaking trend functions in macroeconomic variables. Journal of Econometrics, 80(2), 355-385.

Perron, P., \& Vogelsang, T. J. (1992). Nonstationarity and level shifts with an application to purchasing power parity. Journal of Business and Economic Statistics, 10(3), 301-320.

Pesaran, M. H., Shin, Y., \& Smith, R. J. (2001). Bounds testing approaches to the analysis of level relationships. Journal of Applied Econometrics, 16(3), 289-326.

Phillips, P. C. B. (1999). Discrete Fourier Transforms of Fractional Processes. Yale University Cowles Foundation for Research in Economics Working Paper, No: 1243.

Phillips, P. C., \& Perron, P. (1988). Testing for a unit root in time series regression. Biometrika, 75(2), 335346.

Pigou, A. C. (1917). The value of money. The Quarterly Journal of Economics, 32(1), 38-65.

Rao, B. B., \& Kumar, S. (2011). Is the US demand for money unstable? Applied Financial Economics, 21(17), 1263-1272.

Robinson, P. M. (1995). Log-periodogram regression of time seris with long range dependence. Annals of Statistics, 23(3), 1048-1072.

Shin, Y., Yu, B., \& Greenwood-Nimmo, M. (2014). Modelling Asymmetric Cointegration and Dynamic Multipliers in a Nonlinear ARDL Framework. In Festschrift in Honor of Peter Schmidt (pp. 281-314). Springer, New York, NY.

Sianturi, R. H., Tanjung, A. F., Leong, C. M., Puah, C. H., \& Brahmana, R. K. (2017). Financial liberalization and divisia money demand in Indonesia. Advanced Science Letters, 23(4), 3155-3158.

Sichei, M. M., \& Kamau, A. W. (2012). Demand for money: Implications for the conduct of monetary policy in Kenya. International Journal of Economics and Finance, 4(8), 72-82.

Sollis, R. (2009). A simple unit root test against asymmetric STAR nonlinearity with an application to real exchange rates in nordic countries. Economic Modelling, 26(1), 118-125.

Stokes, H. H., \& Neuburger, H. (1979). A note on the stochastic structure of the velocity of money: Some reservations. The American Economist, 23(2), 62-64.

Suliman, S. Z., \& Dafaalla, H. A. (2011). An econometric analysis of money demand function in Sudan, 1960 to 2010. Journal of Economics and International Finance, 3(16), 793-800.

Tavlas, G. S. (2015). In old chicago: Simons, Friedman, and the development of monetary-policy rules. Journal of Money, Credit and Banking, 47(1), 99-121.

Villeneuve, J. F., \& Handa, J. (2006). Purchasing power parity as a long-term memory process: Evidence from Canada. Applied Financial Economics, 16(1-2): 109-117.

Wang, Y. (2011). The stability of long-run money demand in the United States: A new approach. Economics Letters, 111(1), 60-63. 
Wright, J. H. (2000). Alternative variance-ratio tests using ranks and signs. Journal of Business and Economic Statistics, 18(1), 1-9.

Yılancı, V. (2012). Türkiye'de para talebi istikrarlılığının testi: Kayan pencerelerde sınır testi yaklaşımı. Dumlupınar Üniversitesi Sosyal Bilimler Dergisi, 33, 67-74.

Yu, B., Chun, S. E., \& Kim, J. (2013). Some evidence on the asymmetry of interest rate pass-through in Asian economies. Korea and the World Economy, 14(2), 207-233.

Zhang, Z., Tsai, S. L., \& Chang, T. (2017). New evidence of interest rate pass-through in Taiwan: A nonlinear autoregressive distributed lag model. Global Economic Review, 46(2), 129-142.

Zivot, E., \& Andrews, D. W. K. (1992). Further evidence on the great crash, the oil price shock and the unit root hypothesis. Journal of Business and Economic Statistics, 10(3), 251-270. 